\title{
Más allá de los problemas de género(s): El enigma del reconocimiento de la Monja Alférez a partir del relato «trans» de la Historia de la Monja Alférez (1625)
}

\author{
Lise Segas ${ }^{1}$ \\ Université Bordeaux Montaigne \\ lisesegas@gmail.com
}

Recepción: 15/04/2015, Aceptación: 21/06/2015, Publicación: 22/12/2015

\section{Resumen}

El objetivo del presente artículo es reflexionar sobre el reconocimiento enigmático del personaje transgresivo de la Monja Alférez a partir de un texto que desafía las tentativas de categorización: Historia de la Monja Alférez (1625). Sin amalgamar género sexual/social y género literario, se observan no obstante intersecciones entre la indeterminación literaria de este relato escrito en primera persona y la confusión identitaria del protagonista, probable autor(a) de la obra. Transgenéricos, relato y personaje obligan al lector a no pensar según una lógica genérica sino a repensar el funcionamiento por géneros y su arbitrariedad. Concebida con el propósito de apoyar la petición del reconocimiento de los servicios americanos de la Monja Alférez, Historia de la Monja Alférez opera, a partir del relato del viaje a y por América, una transformación de lo transgresivo en aventuras literarias tradicionales que hacen del protagonista un héroe popular. Además, el texto se inserta en una campańa de promoción más vasta que evidencia la importancia de otros factores que afloran en el relato (estamento, religión, origen cultural, etc.), de las redes clientelares y de la influencia de los vascos, a la hora de explicar el éxito de la Monja Alférez.

Palabras clave

Monja Alférez; reconocimiento; géneros; viajes; América

\begin{abstract}
Beyond gender/genre problems: The enigma of the Monja Alferez's recognition starting from the "trans" tale of Historia de la Monja Alferez (1625)
\end{abstract}

1. EA 3656 AMERIBER, Université Bordeaux Montaigne. 
This paper analyses the enigmatic recognition of the transgressive character of the Monja Alférez starting from a text which challenges the attempts of classification: Historia de la Monja Alférez (1625). Without merging sexual/social gender and literary genres, it can be observed however intersections between the literary vagueness of this first-person written story and its protagonist identity confusion, likely the author of the work. Transgender, story and character compel the reader not to think according a gender/ genre logic but to think over the genre/gender functioning and its arbitrariness. Conceived to support the petition to recognize the American services of the Monja Alférez, Historia de la Monja Alférez changes, thanks to the story of a travel to and through America, transgression into traditional literary adventures thus creating a popular hero. Moreover, to understand the success of the Monja Alférez, we must take into consideration that the text integrates a larger promotional campaign which highlights the importance of other factors appearing in the story (estate, religion, cultural origine, etc.), of the lobbyings and of the Basque influence.

\section{Keywords}

Monja Alférez; recognition; genres; travels; America

Casi todo se ha escrito sobre la Historia de la Monja Alférez, Catalina de Erauso, escrita por ella misma y el personaje epónimo, ambos misteriosos y creadores de un amplio espectro hermenéutico; sin embargo, parece que queda todo por decir. ${ }^{2}$ A partir de esta paradoja previa y de mi propia lectura del texto, trataré de abrir y seguir nuevas pistas de reflexión que puedan completar o matizar los diferentes enfoques críticos. ${ }^{3}$

Conviene recordar ahora a los actores y los medios que intervinieron en la transmisión de esta historia singular hasta hoy. No se conoce el manuscrito au-

2. Tres ediciones fueron consultadas: la princeps realizada por Joaquín María de Ferrer en 1829 y publicada en París, la edición crítica de referencia de Rima de Vallbona, con un título diferente (Vida i sucesos de la Monja Alférez), que salió en 1992 en los Estados Unidos y la más reciente, a cargo de Ángel Esteban, que retoma el título de Ferrer, publicada por Cátedra por primera vez en 2002. Cito siempre por la edición de Esteban. Todas las referencias aparecen en la bibliografía.

3. Quisiera agradecer aquí a mis colegas y amigos Isabelle Touton, Rafael Bonilla, Pierre Darnis, Oswaldo Holguín y Antoine Ventura por sus consejos sutiles, sus sugerencias bibliográficas pertinentes, sus lecturas atentas y las charlas apasionantes acerca del tema. 
tógrafo de la obra, pues, según el texto mismo, las fechas que salen en él y otros documentos encontrados en diferentes archivos, fue compuesto durante el viaje de regreso de la Monja Alférez, en 1624. Se sabe que Erauso entregó al editor madrileño Bernardino de Guzmán un manuscrito en $1625 .{ }^{4}$ Gracias a una larga cadena de amanuenses que se suceden y a pesar del silencio que ocurre entre la segunda mitad del siglo XVII y la segunda mitad del siglo XVIII, el texto nos llega con la edición publicada por José María de Ferrer en 1829 en París que es, pues, la edición princeps. Explica Ferrer que se valió de un manuscrito de su amigo Felipe Bouza, copia a su vez de otro guardado en la Real Academia de la Historia de Madrid y que procede de la famosa colección de manuscritos de Indias de Juan Bautista Muñoz. Este último lo copió a partir de otra copia efectuada por Cándido María Trigueros, poeta y dramaturgo del siglo XVIII. ${ }^{5}$ La conexión de Trigueros con copias o ediciones anteriores de la obra pasa posiblemente por la familia vasca Urbizu: Trigueros sacó una copia del texto de un cuaderno de un tal Domingo de Urbizu, radicado en Sevilla (Alguacil Mayor de la Casa de Contratación), que tenía vínculos con el Nuevo Mundo. ${ }^{6}$

No cabe la menor duda de que Catalina de Erauso existió y vivió muchas aventuras a uno y otro lado del Atlántico. Numerosos testimonios (entre ellos su partida de bautismo, relaciones militares en que aparecen sus hazañas, un expediente que consta de varias peticiones, certificaciones, y que fue presentado al rey en 1626 para pedir el reconocimiento de sus servicios y méritos) constituyen pruebas irrefutables de su existencia andariega y excepcional. Dos relaciones de su vida supuestamente sacadas del original que Erauso dejó al editor madrileño vieron la luz en 1625 (una en Madrid y la otra en Sevilla, a cargo de Simón Fajardo) mientras que se cuenta el final de su vida en Nueva España en una relación impresa en México en 1653 por la viuda de Bernardo Calderón. ${ }^{7}$ Es necesario recordar que en 1625 o a principios de 1626 se estrenaba también una comedia compuesta por Juan Pérez de Montalbán y titulada La Monja Alférez. ${ }^{8}$ Por fin se conocen desde hace poco dos nuevos manuscritos localizados por Pedro Rubio Merino en el Archivo Capitular de Sevilla, dos copias — inacabada la segundaque presentan ciertas diferencias con el texto de Ferrer. ${ }^{9}$

4. Si tal fue el caso, los últimos capítulos (XXIII-XXVI) que relatan acontecimientos posteriores fueron añadidos después: se mencionan fechas precisas (agosto de 1625 o julio de 1626) para referirse a la decisión del rey y a la estancia en Roma y Nápoles. Areta Marigó (1999: 241-242). Esteban (2002: 27).

5. Areta Marigó (1999: 241-242).

6. Esteban (2002: 27).

7. Las referencias bibliográficas se encuentran en Vallbona (1992: 224) y las reproducciones de los textos - a partir de copias para las dos relaciones españolas ya que no se conocen las ediciones originales_ también en Vallbona (1992: 160-175).

8. Ferrer reproduce la integralidad de la obra en su edición. La comedia no pudo escribirse antes de 1625, ya que Erauso regresó de América a finales de 1624, y después de 1626 puesto que termina anunciando que la Monja está en Roma, lo que ocurre en 1626.

9. Areta Marigó (1999: 242). 
El personaje histórico (y posible autor, según el título) del que se alimenta el protagonista de la Historia de la Monja Alférez, Catalina de Erauso, escrita por ella misma tiene una identidad nominal algo confusa, ya que se le conoció por aquel entonces, tanto en la realidad como en el relato, como Catalina de Erauso, Francisco de Loyola, Alonso Díaz Ramírez de Guzmán, Antonio de Erauso o la Monja Alférez. ${ }^{10}$

Por razones obvias y justificadas en parte, la obra es actualmente estudiada por varios especialistas desde la cuestión del género para tratar de comprender el reconocimiento oficial del que se benefició Erauso. ${ }^{11}$ Asimismo, otros han intentado explicarlo a partir de la construcción identitaria del personaje a través del texto autobiográfico, ${ }^{12}$ con todos los problemas que plantea el anonimato del autor del manuscrito original perdido de la Historia de la Monja Alférez. ¿Autobiografía? ¿Biografía presentada como una autobiografía? ¿Texto escrito a cuatro manos? Por ahora nadie puede responder con certeza a estas preguntas; ${ }^{13}$ pero sí se puede descartar la idea de la superchería avanzada por Menéndez Pelayo a partir de las sospechas que despertó en él la fama del último copista del manuscrito perdido, Cándido María Trigueros, célebre por sus falsificaciones literarias en el siglo XVIII. ${ }^{14}$ Muchos abogan hoy por la solución de una escritura a cuatro manos, ${ }^{15}$ con un relato original (oral o escrito) de Erauso.

Además de los problemas atinentes a la autoría y de las consiguientes dudas en cuanto a la dimensión ficcional de buena parte del texto, se plantean nuevas

10. En este trabajo, me referiré al personaje — histórico o narrativo- con su apellido Erauso o su sobrenombre la Monja Alférez por razones de respeto a su identidad transgenérica. Cuando uso "Catalina de Erauso", aludiré a la identidad oficial con la que se le bautizó y con la que fue reconocida por las instituciones como otro rol social que le fue impuesto.

11. Los trabajos de Adrienne L. Martin (1994), James J. Pancrazio (2001), Aránzazu Borrachero Mendíbil (2006) y Chloe Rutter-Jensen (2007) son unos brillantes ejemplos de esta tendencia.

12. Stephanie Merrim (1993), Belén Castro Morales (2000), Sonia Pérez Villanueva (2004) abordan este aspecto de forma muy pertinente.

13. Comparto la conclusión de Sonia Pérez Villanueva (2004: 1449): «Hay varias razones para creer que la propia Catalina de Erauso fue, si no la autora, la narradora de sus aventuras. La existencia y notoriedad de su personaje pudieron ser motivo suficiente para que la Monja Alférez viese la necesidad de contar su historia para contrapesar los correveidiles escandalosos que fueron de corral a taberna, de plaza a iglesia. No obstante, esto no prueba que las ediciones a las que tenemos acceso hoy en día fuesen el texto que Catalina de Erauso narró en un principio. Copistas y editores han podido modificar, con fines de marketing, el manuscrito original dando un carácter más sensacionalista a la obra.»

14. En la introducción al texto, Rima de Vallbona (Vallbona, 1992: 17-19) explica que Trigueros, aunque fuera muy capaz de reproducir la lengua y el estilo de principios del siglo xviI, no hubiera podido proporcionar tantos detalles históricos acerca de las andanzas araucanas de Erauso ni relatar con tanta soltura y espontaneidad ciertos acontecimientos subversivos.

15. Se podría aducir otro argumento a favor de esta hipótesis (tomando en cuenta una participación muy activa de Erauso en la elaboración del texto): conocía el latín, como lo explica el relato (cap. I) ya que uno de sus amos, el doctor Francisco de Cerralta se lo enseñó. Además sabemos que contaba muy bien ya que varios mercaderes le encargaron sus tiendas, con cuentas que hacer y mucho dinero que manejar (Pérez Villanueva, 2004: 1446). 
interrogaciones acerca de la construcción del relato y de la dimensión del personaje de la Historia de la Monja Alférez según una lógica (auto-)promocional (no olvidemos que Erauso mandó al rey su petición para conseguir una renta y el reconocimiento oficial de sus servicios) y de las estrategias sabiamente orquestadas para lograr tal resultado.

Para entender cómo pudo conseguir el reconocimiento de las máximas autoridades patriarcales e institucionales de la época (el rey y el papa) es inevitable encarar la problemática de los géneros (sexual, social, literario) como pieza del enigma. Ahora bien, ¿qué importancia y qué dimensión darle sin caer en un enfoque reductor cuando no anacrónico? Por ello, no quiero descartar otros factores que afloran en el relato, que fueron fundamentales en aquella época y aún más determinantes en el proceso del reconocimiento (aunque menos espectaculares y propensos a la dramatización), y que permitirán circunscribir un contexto más amplio: el estamento, el origen cultural, la religión de la persona o, en el caso del planteamiento que voy a adoptar, la importancia del viaje transatlántico y transamericano. ${ }^{16}$

Mi trabajo se va a concentrar en el proceso de elaboración y de (auto-) representación del personaje protagonista de la Historia de la Monja Alférez sin desdeñar de vez en cuando otros avatares de la Monja Alférez (héroe de relatos anexos ya citados o modelo de retratos pictóricos) puesto que considero que forman parte de lo que he dado en llamar «una vasta campaña de promoción» llevada por el personaje histórico y su entorno. Se considerarán varios aspectos conjugados alrededor de la idea de polimorfismo genérico (en todos los sentidos del término, literario, sexual y cultural), potenciado por la idea de aventuras en tierras americanas. Por otra parte, esta última idea es un aspecto poco estudiado ${ }^{17}$ que me parece sumamente relevante en el acercamiento al relato: la relación que el personaje protagonista desarrolla con el espacio, ya sean espacios geográficos (Viejo y Nuevo Mundo, márgenes y centro, numerosas etapas, viajes incesantes), espacios sociales (el mundo masculino como espacio abierto, público, militar y en movimiento, y el mundo femenino como espacio cerrado, privado, pacífico y fijo, posición social, racial, en la hermandad) o espacios simbólicos (literatura y cultura, tópicos). La movilidad podría ser la palabra clave para definir a este personaje, que queda inaprensible a pesar de cuántos anzuelos se le tira. El proceso de construcción identitaria se plasma a través del viaje y de su narración.

16. La historia empieza así: «Nací yo, doña Catalina de Erauso, en la villa de San Sebastián...» (93). Si los estudiosos recalcaron la identidad oficial femenina con la que se abre el relato, sacando diversas conclusiones sobre las cuales volveré más adelante, nadie reparó en la palabra antepuesta: «doña». La afirmación de su origen noble parece aún más importante que su pertenencia genérica original. Desarrollaré esta idea así como la de la puesta de relieve de su pertenencia étnica.

17. Castro Morales (2000) y Rutter-Jensen (2007) proponen interpretaciones muy interesantes al respecto. 
Desde el Descubrimiento, América siempre ha sido para muchos europeos el continente de la realización del modelo del self-made man. Aún más para los que iban de segundones o para los seres marginados en una sociedad fuertemente regida por los criterios del género sexual y cultural (dominado por el patriarcado), social (estamentos, linajes), espiritual (religión católica) y racial. ${ }^{18} \mathrm{~A}$ partir de su huida del convento cuando era todavía joven (una novicia que no había profesado aún), la Monja Alférez viaja por España y luego por América, llevando ropa de hombre y portándose como un hombre. Peregrina durante más de veinte años por las Indias, recorriendo casi la totalidad del virreinato del Perú, y realiza cerca de cincuenta etapas en diferentes ciudades, puertos, ventas o pueblos de indios en los cuales inevitablemente mata, hiere, brega, sin descubrir jamás su identidad hasta el final. La etapa se vuelve motor narrativo, la aventura nace de los encuentros fortuitos que hace la Monja Alférez. Se esboza un mundo americano agitado, peligroso, inestable, en el que el viaje continuo es un modo de vivir y, en el caso de nuestra protagonista, de sobrevivir salvando su secreto y su integridad física de virgo bellatrix. La vida errante constituye también la base de una estructura narrativa dinámica, híbrida, cuyas fuentes literarias brindan al texto y a la protagonista la posibilidad de convertirse en verdadero héroe popular. No hay que olvidar que la Monja Alférez se volvió instantáneamente una verdadera estrella en ambos lados del Atlántico.

Eminentemente barroco, ${ }^{19}$ este personaje ambiguo transgrede ciertas normas sociales, culturales y legales a lo largo de su periplo americano. La Monja Alférez (un seudónimo que reúne en un oxímoron una función femenina que remite al encierro y una función masculina vinculada a la guerra y el viaje) es un personaje totalmente «trans»" ${ }^{20}$ sus viajes son transatlánticos y transamericanos, sus identidades así como su obra son transgenéricas y transitorias, mediante el travestismo se vuelve un transeúnte transgénero. Dicho de otro modo, el prefijo «trans», que se aplica a todo lo que Erauso hace, expresa la idea del desplazamiento perpetuo, una calidad precisamente negada a las mujeres del xviI. Con la Monja Alférez desaparecen las fronteras, las separaciones tradicionales. Se coloca en la intersección o la transición entre lo femenino y lo masculino, las armas y las letras, Europa y América, etc.

Asimismo, este artículo se sitúa teórica y metodológicamente en una perspectiva transdisciplinar y multifocal, ya que se apoya a la vez en los valiosos resultados de los estudios culturales (estudios de género, queer, feministas, historia cultural), en un enfoque sociocrítico que intente tomar en cuenta los contextos de producción y recepción (aspectos interdiscursivos) de la obra y en un análisis de índole más estructuralista al considerar las estrategias narrativas. Me intere-

18. Zavala, Luna (1997: 247).

19. En su famosa obra La cultura del Barroco, José Antonio Maravall (1975: 362-363) insiste en lo mudable como característica del Barroco.

20. Lo subraya también Rutter-Jensen (2007: 86). 
saré pues por la cuestión, muy problemática, del reconocimiento —en el relato (anagnórisis y su función narrativa; identificación con personajes literarios tradicionales), en el marco de las instituciones (por el rey), y según la norma moral (el Papa le permite llevar ropa de hombre) y finalmente en el mundo académico actual- de este personaje subversivo y polifacético, construido a partir de un texto literario sabiamente elaborado para promocionar a un militar ejemplar. Sin embargo, ¿qué es lo que se le reconoce realmente? ¿Su heterodoxia o su ortodoxia? ¿Cuál es la verdadera dimensión de este reconocimiento rápido y unánime por parte de las autoridades y de la publicidad que se hace de él?

\section{Las lecturas genéricas de la Historia de la Monja Alférez: aciertos y límites}

\section{Un relato hibrido}

Las dificultades para categorizar el relato de la Historia de la Monja Alférez según una terminología posterior van a revelar los límites de la taxonomía literaria en cuanto al corpus moderno en general y americano en particular, y a evidenciar las interferencias sabiamente destiladas para hacer de la confusión identitaria el aparente motor narrativo.

La mujer noble del siglo XviI solía tener dos opciones - aunque no era una regla absoluta: casarse con un hombre o casarse con Dios. Según lo que elegía, se encerraba en una casa o en un convento. Su visibilidad tenía que pasar por el marido y no tenía acceso al uso público de la palabra. Pocas son las mujeres, como Leonor López de Córdoba en el siglo xv, que se atreven a tomar la pluma y contar sus vidas. ${ }^{21}$ Pero el fenómeno florece a principios del siglo XVII con las autobiografías espirituales de monjas que encuentran en el encierro cierta libertad para escribir, ${ }^{22}$ siempre bajo la mirada del confesor, su vida dentro del convento. Por otra parte, el relato autobiográfico es también la forma que escoge la novela picaresca para contar la vida ficticia de sus antihéroes vagabundos ${ }^{23}$ introduciendo en el espacio literario lo transgresivo, lo rechazado por la sociedad.

La Historia de la Monja Alférez parece precisamente empezar como una autobiografía que podría estar en el cruce entre la novela picaresca y la autobiografía espiritual. El relato picaresco suele referirse a un mundo masculino con héroes masculinos (aunque no es un imperativo, como lo demuestran La picara Justina o La Lozana andaluza) y la autobiografía espiritual a un mundo conventual femenino (la última parte del título, «escrita por ella misma» recuerda, por ejemplo, la del título de la obra de Santa Teresa, La vida de la Santa Madre Teresa de Jesús, $y$ algunas de las mercedes que Dios le hizo, escritas por ella misma). La mezcla de

22. Zavala, Herpoel (1997: 215-223).

23. Esteban (2011: 54-55). 
ambos géneros es evidente en el primer capítulo de la obra y genera desde el principio oscilaciones fundamentales entre géneros (sexual, social y literario - cuya asociación es en muchos casos reveladora). Presenta primero su nombre oficial, su ascendencia y su lugar de nacimiento: «Nací yo, doña Catalina de Erauso, en la villa de de San Sebastián, de Guipúzcoa, en el año de 1585, hija del capitán don Miguel de Erauso y de dońa María Pérez de Galarraga y Arce, naturales y vecinos de dicha villa» (93). La historia de su infancia sigue con la del noviciado en el convento de San Sebastián el Antiguo y la vida conventual con las dominicas (episodio de pendencia con otra monja), pero sin ninguna dimensión mística, antes de relatar su huida, su transformación física (se masculiniza al cortarse el cabello y vestirse con ropa de hombre) y el servicio a varios amos tanto en la Península como en América. Las aventuras picarescas, en casas de juego - la Monja Alférez muestra una afición enfermiza a los juegos de naipes - o en tabernas, las riñas que se arman introducen un mundo muy masculino, violento, en el que Erauso tiene que defenderse $-\mathrm{y}$ atacar muchas veces - a espadazos. Esta secuencia narrativa de índole picaresca ocupa los cinco primeros capítulos.

La confluencia de los géneros - con el predominio claro del relato picaresco- y la figura huidiza del autor de la Historia de la Monja Alférez llevan a James J. Pancrazio a formular la idea del texto apócrifo a partir del problema del género sexual, socavando así el pacto autobiográfico establecido por Philippe Lejeune (la correspondencia entre autor, narrador y personaje): «How can Vida $i$ sucesos be Catalina's autobiography when it is the story of Antonio's exploits?». Se cuestiona tanto la dimensión autobiográfica del texto como el género autobiográfico cuya «classification as a genre necessarily places it in conflict with the notions of fiction and history ${ }^{24} \mathrm{o}$ como la adecuada aplicación al relato del término "autobiografía», según la definición que Lejeune establece a partir de las autobiografías confesionales de tipo rousseauniano. ${ }^{25}$ En efecto, nunca se nos da a leer o a conocer los sentimientos, la intimidad, los conflictos psicológicos del personaje; se nos presentan solamente sus actos, a la manera de una relación de méritos y servicios. La oscilación entre la palabra «historia» y la palabra "vida» en función de las ediciones viene a confirmar la resistencia de este relato a las categorizaciones tajantes.

El relato de la Monja Alférez se presenta entonces como una historia centrada en un solo individuo (que es en realidad varias personas simultánea o sucesivamente), en una trayectoria personal, lo que implica, por parte del autor, una selección de acontecimientos y un tratamiento orientado hacia cierto fin, en nuestro caso la representación de una figura excepcional, extraordinaria para lograr el reconocimiento de sus méritos y servicios al rey. Recurre pues a otro género muy de moda, el de la autobiografía militar o probanzas de méritos. Este

24. Pancrazio (2001: 465).

25. Amelang (2006: 149-150). 
tipo de relato florece con la Conquista de América ya que muchos soldados quieren obtener premios por sus servicios. Representativa del género humilde, la relación de méritos y servicios es, como recuerda Belén Castro Morales, el modelo original de la novela picaresca. ${ }^{26}$

No obstante, como para enredar al lector, puede también recurrir a una dimensión épico-histórica que ennoblece el relato; se expresa particularmente en el capítulo VI, uno de los más largos, en el que se cuentan las guerras de Chile, las proezas del soldado Alonso Díaz Ramírez de Guzmán que se va a ganar el grado de alférez después de una acción espectacular que le permite recuperar la bandera espańola: «Yo recibí un mal golpe en una pierna, maté al cacique que la llevaba y quitésela, y apreté con mi caballo, atropellando, matando e hiriendo a infinidad, pero malherido y pasado de tres flechas y de una lanza en el hombro izquierdo, que sentía mucho» (114). El ejemplo citado muestra la gran eficacia de la narración del episodio: en pocas palabras, mediante una acumulación de acciones que confieren a las frases dinamismo, gracias a las referencias a lugares, topónimos (Valdivia, Chile, Purén) y acciones consagrados por la gran epopeya imperial de Ercilla y a la aparición de un nuevo San Sebastián sacrificado en el altar de la conquista militar y espiritual de los araucanos, el/la narrador(a) se representa como un ejemplo de masculinidad heroica. ${ }^{27} \mathrm{La}$ épica fue uno de los géneros predilectos de aquellos que buscaron fortalecer de nuevo el heroísmo militar como proveedor de recompensas.

Estos episodios contrastan con el énfasis, muchas veces hiperbólico, con el que se narran otros episodios moralmente condenables. Sin embargo, forman parte de una sola estrategia narrativa: la justificación "por vía de la excepcionalidad». ${ }^{28}$ Castro Morales añade, apoyándose en los trabajos de Stephanie Merrim, que el proyecto narrativo corresponde a la cultura del Barroco. Maravall explicó que lo espectacular, lo extraordinario sirvió para cautivar a las masas y hasta para suspender su vigilancia moral. ${ }^{29}$ Desviar la atención del lector, recurrir a una estrategia de la diversión —es un militar hábil—, en el doble sentido de la palabra (entretenimiento y desviación de la mirada), son otros medios narrativos que comparte justamente con la épica culta histórica. ${ }^{30}$ Como bien destaca Aránzazu Borrachero Mendíbil, «al apoyarse en una simple enumeración de acciones y evitar una declaración de intencionalidad en ellas, la atención del lector permanece enfocada en lo que parece ser el objetivo primero de Erauso: disfrazarse para no ser hallada y devuelta al convento». ${ }^{31}$ Dicho de otra manera: la mirada

26. Castro Morales (2000: 233).

27. La referencia implícita a San Sebastián puede remitir a sus orígenes vascos que no deja de recordar a lo largo del relato.

28. Castro Morales (2000: 238).

29. Maravall (1975).

30. Segas (2011: 572).

31. Borrachero Mendíbil (2006: 488). 
del lector permanece enfocada en la condición de mujer disfrazada de hombre, un tópico literario que se aprovecha con gran astucia.

Por consiguiente su excepcionalidad nace de dos aspectos: la confusión genérica que lo/la caracteriza y que se expresa en un relato transgenérico y la vida y hazañas extraordinarias que realiza. Ahora, cabe preguntarse por qué el/la narrador(a) construye su relato (auto-)biográfico de esta manera. La respuesta es a la vez muy sencilla y muy compleja: dedica la mayor parte del relato a sus aventuras vividas como hombre (identidad y comportamiento) pero su vida queda literalmente enmarcada por su nacimiento y su reconocimiento como mujer. Como demostró James Pancrazio, la autobiografía plantea el problema de los géneros literarios en general, y sexuales y sociales en particular. ${ }^{32} \mathrm{El}$ conflicto con la categorización precisa y la norma se traducen en el texto bajo la forma de una ecuación aparentemente imposible: quiere ser un hombre y debe ser una mujer.

\section{Género e identidad en la época moderna}

En el Renacimiento, una de las teorías anatómicas vigentes es la del sexo único, ${ }^{33}$ de origen galénico. Galeno había establecido el unisexo, un sistema en el cual la mujer es una variación debilitada, inferior, del hombre. Es decir que el sexo se evalúa en términos de escala vertical, de grados, cuando en el sistema bisexual la diferencia es horizontal: el uno no es el otro, es su contrario, no su variante (aunque inferior). Según Thomas Laqueur, antes del siglo xviır y de la invención de la biología después de los progresos de la anatomía en el marco de la afirmación de un modelo burgués regido por la idea de transmisión del patrimonio, el sexo era únicamente determinante a nivel social, no a nivel ontológico: «Pendant le plus clair du XviI siècle, être homme ou femme c'était tenir un rang social, assumer un rôle culturel, et non être organiquement de l'un ou l'autre sexe. Le sexe était encore une catégorie sociologique, non pas ontologique» (161). Dicho de otra manera, no se sexualizaba necesariamente el género aunque la asociación entre ambos —el género y el sexo- era tradicionalmente establecida ${ }^{34}$ pero no

32. Pancrazio (2001).

33. Véase la obra apasionante de Thomas Laqueur (1992), La fabrique du sexe. Essai sur le corps et le genre en Occident. Este ensayo es ineludible para quien quiere acercarse a cuestiones de géneros/sexos. 34. Laqueur refiere varios casos de mutación genérica siempre vinculada y validada con un cambio fisiológico de sexo (lo que de cierta forma invalida una parte de su tesis). Aunque el sexo es la consecuencia, la traducción fisiológica del género de una persona - y no la causa de su génerola interdependencia entre ambos parece más importante de lo que su tesis deja pensar. Montaigne relata ciertos casos en sus Ensayos, variando los géneros gramaticales en función del género reconocido de la persona (véase «De la force de l'imagination» por ejemplo). O sea que se podía producir «espontáneamente» un cambio de sexo (en general una mujer se volvía hombre y no lo contrario — que hubiera sido una regresión según la teoría galénica), lo que se interpretaba como la manifestación física del género como característica ontológica. Laqueur cita a Paolo Zacchia y su Questionum medico-legalium: «Les membres qui se conforment au sexe sont non pas les causes qui constituent le mâle ou le femelle ou encore les distinguent l'un de l'autre [...]. Parce qu'il se trouve que les membres de l'un des sexes pourraient apparaitre chez quelqu'un du sexe opposé» (159). Sin embargo, sin cambio físico, se 
incambiable. Si una mujer puede «medrar» al transformarse en hombre, lo contrario sería imposible; sin embargo, para que esta transformación sea válida, se necesita tener las características físicas que lo atestiguen. Yo lo formularía de manera algo distinta, introduciendo el matiz de la dependencia entre género y sexo (con el primero que determina el segundo) que me parece imprescindible para poder comprender las mentalidades de aquella época: el sexo es la consecuencia física del género —ontológico- de una persona pero no es la causa.

El caso de la Monja Alférez es verdaderamente excepcional: una persona nacida con genitales femeninos se va a masculinizar y hasta hipermasculinizar para vivir una vida de hombre, sacando provecho de un cuerpo poco femenino, de atuendos y actitudes masculinos pero sin cambiar de sexo (algo materialmente imposible). Los retratos (pictóricos o literarios) que se hicieron de Erauso muestran sin embargo la necesidad — complicada — de encasillarlo/la en una categoría física, lo que revela la imposibilidad de pensar de manera diferenciada sexo social — género- $\mathrm{y}$ sexo físico. El retrato realizado por el sevillano Francisco Pacheco en $1630^{35}$ representa a Erauso con elementos masculinos (con ropa de hombre y una expresión agresiva) pero con rostro imberbe — a pesar de la edad avanzada indicada arribaque recuerda su condición física de mujer así como el título del lienzo que anuncia su identidad oficial («doña Catalina de Erauso»). El retrato literario que hace de Erauso Pedro della Valle traduce también la obligación imperiosa de categorizarla según la norma binaria genérica que prevalece, a pesar de la dificultad planteada:

Ella es de estatura grande y abultada para muger, bien que por ella no parezca no ser hombre. No tiene pechos: que desde que mui muchacha me dixo haver hecho no sé qué remedio para secarlos y quedar llanos, como le quedaron: el cual fue un emplasto que le dio un Ytaliano, que quando se lo puso le causó gran dolor; pero después sin hacerle otro mal, ni mal tratamiento, surtió el efecto. [...] En efecto, parece más capón que mujer. ${ }^{36}$

Como nota Pancrazio (2001: 461), la doble negación del principio y la categoría de "capón» expresa cierta duda o cierta turbación a la hora de atribuirle un sexo físico que corresponda con su género ambiguo. Habla de ella como de una mujer ("ella», "muger») y no como de un hombre. Más adelante menciona las características físicas que, según él, la asemejan a un hombre («los cabellos son negros y cortos como de hombre», «viste de hombre a la española») ${ }^{37}$.

condenaba a la persona que se portaba como hombre o mujer a pesar de su sexo; la libre elección del género no era algo aceptado. Lo que no se pone de realce a propósito de las fuentes estudiadas por Laqueur es que todas son juicios, documentos sacados de archivos judiciales, de plebeyos, de personas humildes. No se estudian en el marco más amplio de una contextualización socioeconómica para ver si factores sociales (estamentos) pueden interferir para agravar o minimizar el delito.

35. Existe otro retrato pintado por el italiano Francisco Crescencio en 1626 que no he podido ver.

36. Vallbona (1992: 128).

37. Ferrer (1829: 126-127). 
Ahora bien, lo que parece ser un problema en nuestro caso es el de la validación del género masculino escogido por Erauso, a falta de una transformación física. Uno de los principales recursos inventados es lo que Rutter-Jensen llamó una "operación narrativa» ${ }^{38}$, ya que su «identidad es menos una cosa fija que un proceso narrativo». ${ }^{39}$ Para realizarla, el relato se vale de tres procesos: la multiplicación de modelos literarios tradicionales como otras tantas máscaras, la inscripción en un discurso masculino con códigos patriarcales, la confusión genérica literaria.

Un elenco de personajes literarios y/o míticos la convierten en un personaje a su vez literario, ficticio, que escapa a la realidad y le permiten expresar la transgresión en un mundo leído según los códigos de la literatura. La identidad literaria que prevalece en el relato es la de la mujer disfrazada de hombre.

Con el Descubrimiento y la Conquista de América, se reactivaron antiguos mitos. Tierra real e irreal a la vez, el nuevo continente se lee en clave de referencias literarias y míticas occidentales. Los personajes mitológicos femeninos como las amazonas aparecieron a orillas del gran río, según Fray Gaspar de Carvajal, el cronista de Francisco de Orellana, para reafirmar la Conquista «como una empresa heroica y viril de expansión de la 'civilización' del Imperio cristiano español ${ }^{40}$. Belén Castro Morales recuerda que durante el Siglo de Oro la representación de tales personajes femeninos fue polémica y condenada por los preceptos aristotélicos (Minturno, el Pinciano, Manuel de Villegas). Sin embargo, a pesar de la desaprobación de ciertos moralistas y con la soberanía del gusto popular, teoría y práctica discrepan, como en otros tantos casos: la figura de la mujer guerrera se difunde en la literatura del Renacimiento después de la introducción en el imaginario occidental de las potencialidades fantásticas americanas. ${ }^{41}$ Para completar la lista de ejemplos de mujeres fuertes reales o ficticias que dan Belén Castro Morales (toma el ejemplo de Isabel de Guevara) y Diana de Armas Wilson (la doña Mencía y las guerreras araucanas como Fresia de La Araucana), ${ }^{42}$ podemos añadir a mujeres excepcionales ${ }^{43}$ como

38. Rutter-Jensen (2007: 87).

39. Rutter-Jensen (2007: 92).

40. Mataix Azuar (2010: 133). Cabe recordar que fue convocado el mito de las Amazonas para mejor recalcar la victoria de los hombres civilizadores que conquistaron y dominaron a una América rebelde personificada como mujer salvaje.

41. Castro Morales (2000: 230). La erotización de la Conquista con el triunfo masculino que doma lo femenino muestra que la «Conquista se alegoriza como un encuentro sensual entre el hombre, depositario del poder, del orden, de la civilización y de la verdad, y todas esas variantes hispánicas de la amazona 'deseosa de ayuntarse con los cristianos', que son, sin duda, construcciones masculinas de la alteridad femenina como lugar de dominio ilimitado aunque no siempre dócil» (Mataix Azuar, 2010: 133).

42. Castro Morales (2000: 231); Armas Wilson (1996: 28-31).

43. Cabe subrayar aquí que en un principio las mujeres excepcionales (se elaboraban listas de mujeres célebres desde la Antigüedad) son las únicas mujeres autorizadas en la esfera pública de la literatura (Benassy, 1979: 86). Sin embargo, se observan algunas apariciones de mujeres reales que asumen papeles tradicionalmente atribuidos a los hombres (militar o intelectual), un fenómeno no obstante muy limitado y que culmina con Sor Juana que milita no solamente por sí sino también por todas las mujeres, evitando así «la trampa del concepto de la mujer-excepción» (Benassy, 1979: 86). 
Isabel Barreto, la esposa de Álvaro de Mendaña, que durante la expedición a las Islas Salomón toma el mando de la expedición y se vuelve de hecho almiranta o a la propia Monja Alférez reconocida como otro ejemplo de mujer fuerte por aquel entonces. ${ }^{44}$

El éxito de la mujer fuerte, en todas sus variantes (virago, puella bellatrix a la Bradamante o a la Marfisa ariostescas) ${ }^{45}$ muy de moda en la literatura fantástico-caballeresca, y de la mujer disfrazada de hombre, muy popular en el teatro, ${ }^{46}$ constituyen las raíces, la justificación casualmente ideal y la sutil máscara de la construcción del personaje. ${ }^{47}$ Forman parte de las estrategias de la representación o autorepresentación de la Monja Alférez.

La mención que se hace del «disfraz» ${ }^{48}$ al principio del relato (cuando huye del convento, de noche, en un bosque - lugar al margen de la sociedad - se corta el pelo y se viste con ropa de hombre que fabrica) y al final (en varios momentos, cuando «revela» su identidad femenina — cap. xvIII — y cuando viaja a Italia) enmarca el relato y permite restablecer la diferencia binaria genérica fundamental que rige la sociedad. El/la narrador(a) insiste en el encubrimiento como en el capítulo VI cuando se topa con su hermano en Chile y procura no ser reconocida: «fui a todo respondiendo como podía, sin descubrirme ni caer él en ello» (112).

El éxito del personaje de la mujer disfrazada de hombre se confirma en la comedia, en obras de Lope de Vega, Vélez de Guevara, Tirso de Molina o Calderón. ${ }^{49}$

44. La identidad original femenina de Erauso, o sea Catalina, se impone oficialmente al final del relato, aunque el Papa le permite llevar ropa de hombre. Muchos documentos - aunque no todos- encontrados en los archivos, que constituyen pruebas de su existencia (testimonios, certificaciones, etc.) insisten en su identidad social oficial femenina, llamándola Catalina de Erauso. 45. Se retoma ahí la tradición de la doncella guerrera, de la virgo bellatrix, que aparece en varios relatos de la Antigüedad (pensemos en Camila de la Eneida) o de su variante más femenina, las amazonas (Pentesilea, Hipólita). A lo largo del Medioevo se sigue sacando provecho de este personaje ambiguo, que reúne a la vez calidades femeninas y viriles, particularmente en los romances o las canciones de gestas francesas como por ejemplo Ide en Huon de Bordeaux. Culmina con las novelas de caballerías y el romanzo italiano. En el Orlando furioso de Ludovico Ariosto (1516), Bradamante y Marfisa se ilustran en el campo de batalla o en los torneos y triunfan (Marín Pina, 1989).

46. Lope de Vega fue uno de los que más protagonismo le brindó a este personaje en sus comedias (Bravo Villasante, 1976).

47. Es imprescindible precisar que por más tentador que resulte aplicar el mito de las amazonas a la Monja Alférez, se observan varias resistencias por parte del personaje en la Historia de la Monja Alférez: niega toda posibilidad de reproducción (sabemos que es parte importante del poder de las amazonas ya que necesitan a sus hijas y excluyen a los varones para prolongar su sistema matriarcal) y por consiguiente rechaza una de las funciones tradicionalmente atribuidas a las mujeres. No reivindica tampoco la dominación — y la afirmación — femenina ya que no realiza sus hazañas militares siendo mujer. Por fin, no excluye lo masculino sino que lo asimila.

48. Utilizo comillas para referirme a su atuendo masculino porque la narración lo presenta así. Sin embargo, la distinción entre máscara y cara no es tan evidente. Ya veremos que el personaje se viste con otros disfraces aunque no los presente como disfraces y que el juego entre apariencias y verdad es totalmente ambiguo y, muchas veces, carnavalesco.

49. Podemos citar de Lope de Vega Las mujeres sin hombres, de Tirso de Molina Las Amazonas en Indias o de Calderón La vida es sueño y el personaje de Rosaura. 
Lope de Vega escribe, en su Arte nuevo de hacer comedias, los versos siguientes: «Las damas no desdigan su nombre, / y, si mudaren traje, sea de modo / que pueda perdonarse, porque suele / el disfraz varonil agradar muchom. ${ }^{50} \mathrm{El}$ éxito popular y literario de este personaje respalda la intriga identitaria del relato y desvía la atención del lector al introducir suspense, lances, equívocos divertidos. Las situaciones que nacen de estos equívocos llevan muchas veces a Erauso a estar en apuros. En el séptimo capítulo, se le hacen cerca de Tucumán dos propuestas de matrimonio que rechaza huyendo para seguir escondiendo su identidad. Estas situaciones se repiten varias veces y Erauso siempre las soluciona huyendo lejos y retomando su vida andante por América. Otra escena del quinto capítulo compromete a Erauso cuando se encuentra en una situación ambigua con una mujer de la familia de su amo y surge el tema muy popular del amor prohibido:

Al cabo de nueve meses me dijo que buscase mi vida en otra parte; y fue la causa que tenía en casa dos doncellas hermanas de su mujer, con las cuales, y sobre todo con una que más se me inclinó, solía yo más jugar y triscar. Y un día, estando en el estrado peinándome acostado en sus faldas, y andándole en las piernas, llegó acaso a una reja por donde nos vio y oyó a ella que me decía que fuese al Potosí y buscase dineros, y nos casaríamos. (109)

No lo presenta por supuesto como lesbianismo propiamente dicho porque la Monja Alférez no actúa como una mujer sino como un hombre, o mejor dicho como un héroe literario masculino - un nuevo burlador, de América esta vez- que corteja a mujeres, intentando adoptar los códigos masculinos para masculinizarse. Además, este tipo de lío amoroso tiene como trasfondo el famoso antecedente ovidiano de Ifis y Yante que supone cierta transformación mágica: en las Metamorfosis, Ovidio cuenta la relación amorosa que existe entre Ifis, una joven cretense criada como un hombre y disfrazada de hombre, y Yante, otra joven mujer, que terminan por casarse después de que los dioses interceden y transforman a Ifis en hombre.

La Monja Alférez es un personaje que provoca la acción; es activo porque pendenciero, aficionado a los juegos de naipes, corteja a ciertas mujeres: le gustan las mujeres bonitas, según lo que confiesa acerca de una de sus pretendientes, «fea como un diablo, muy contraria a mi gusto, que fue siempre de buenas caras» (122). Se afirma como un hombre a lo largo del relato, porque es activa (calidad del hombre de la época) y porque se comporta como un hombre hecho y derecho (guerrea, brega, corteja, etc.). De hecho, a las pocas páginas, después de su huida del convento, se nota un cambio de género, esta vez gramatical, ya que el sujeto abandona el femenino por el masculino. En todas las situaciones viriles se impone el masculino. Se observan pocas vacilaciones entre masculino y femenino gramaticales excepto en casos precisos: al principio cuando, según la

50. Arte nuevo de hacer comedias (2006: vv. 280-83). 
norma social y cultural, es aún una mujer, cuando se siente débil — muy pocas veces: «ya se ve mi aflicción, cansada y descalza» durante el paso por los Andes (121) antes de llorar y rezar, dos actividades tradicionalmente reservadas a las mujeres. En el momento de la revelación final de su identidad al obispo de Guamanga, le dice al prelado "que soy mujer», antes de ańadir "yo llana estoy», en confirmación de su virginidad (160-161).

Esta vida andariega $10^{51}$ expone a ciertos peligros, además de las múltiples heridas, a veces graves, que recibe: el de ser reconocido, la huida ante el matrimonio que podría arruinar su reputación al despertar sospechas sobre sus inclinaciones. Así que parece sentir la necesidad de afirmar su hipermasculinidad ejemplar (con las cicatrices y la musculatura que desarrolla) y su virilidad (portándose como un hombre tanto en las buenas como en las malas acciones). Sus hazañas durante las guerras de Chile, su participación en expediciones para conquistar tierras y buscar oro (conquistador), su pelea contra piratas holandeses (defensor del imperio), sus múltiples rińas con otros jugadores o con hombres (pícaro) que lo molestan en casas de juegos o en la calle constituyen otras tantas oportunidades para esgrimir los instrumentos fálicos que son la espada y la daga.

A pesar de esta vasta empresa de (auto-)representación masculina, el relato se acaba con la anagnórisis final que sella su identidad femenina. Como en la comedia, el orden tiene que ser restablecido y el reconocimiento por parte de las autoridades interviene tan fácil y rápidamente porque la Monja subvierte solamente una parte del sistema: la parte reservada a la mujer pero no el patriarcado ya que adopta un ideal caballeresco, guerrero con valores varoniles, ${ }^{52}$ que recuerda las actuaciones de las mujeres fuertes o viragos; es decir que se viriliza, no reivindica su feminidad, al contrario, se equipara al hombre dentro de un sistema regido por normas patriarcales y varoniles nunca solapadas porque, según las aclaraciones de Laqueur, solamente asciende en la escala genérica. En la Historia de la Monja Alférez, con el reconocimiento final, se opera un desplazamiento de la mujer disfrazada de hombre hacia la virago, es decir la identificación de una femenidad viril posible. En su sobrenombre, que hace referencia a su ambigüedad genérica, la primera palabra, «monja», evoca su virginidad, es decir una forma de autocastración que le permite no ser mujer completamente (igual que el pecho que no se desarrolló gracias al remedio citado por della Valle $)^{53}$ : se completa su perfil con la dimensión de la virgo bellatrix. Marrero-Fente aduce que las autoridades eclesiásticas aceptan y perdonan su situación gracias a su virginidad de monja y no de mujer: «Es cierto que el significado de la virginidad para las monjas no era tanto una cuestión de honor, como para las mujeres seculares,

51. Se impone en las líneas siguientes el masculino porque son los personajes identificados como masculinos (Alonso o Antonio) los que protagonizan los episodios citados.

52. Delpech (1979: 34).

53. Vallbona (1992: 128). 
sino un proceso de alejamiento del estado peligroso, potencialmente corrupto y pecaminoso que implicaba ser mujer. Inclusive se las consideraba más masculinas que por haberse apartado/renunciado a su condición de mujer». ${ }^{54}$ En efecto, lo que siempre se niega en el caso de las mujeres fuertes, de las doncellas guerreras o de las mujeres independientes, en la comedia, en la novela de caballerías, en el romance, en las novelas cortas de María de Zayas ${ }^{55}$ o en el relato de la Monja Alférez es la libertad sexual de la mujer: ${ }^{56}$ este último baluarte queda inviolado y Catalina de Erauso lo evoca con mucho recaudo, insistiendo en su pureza. ${ }^{57}$

No se puede reducir su identidad a un problema de género. Según Geneviève Sellier, presidenta de la Société Internationale pour l'Étude des Femmes de l'Ancien Régime, la noción de género tiene una pertinencia teórica reducida ${ }^{58}$ porque en el Antiguo Régimen la pertenencia sexual le parece menos importante para acceder al poder que la pertenencia social, política o el lugar ocupado en la hermandad, ${ }^{59}$ o sea que, en una sociedad muy marcada por los estamentos, el género, aunque determinante en varias esferas de la vida social, tiene menos peso a la hora de segmentar jerárquicamente los papeles de unos y otros. Al final, Erauso les recuerda agresiva y groseramente a dos mujeres (e indirectamente se lo recuerda el autor al lector) que el problema del género/sexo no es precisamente su problema. En su última etapa en Nápoles, las mujeres le preguntan de manera provocadora, refiriéndose sin duda a su ambigüedad sexual basada en su identidad de mujer (le dicen «señora») y su aspecto varonil (lleva ropa de hombre): «Señora Catalina, ¿dónde es el camino?». Y la Monja Alférez responde: "Señoras putas, a darles a ustedes cien pescozadas, y cien cuchilladas a quien las quiera defender». ${ }^{60}$ Concluye luego la obra con una frase reveladora: «Callaron y se fueron de allí (175). Es la primera vez que ella se queda y no huye a otra parte mientras que los demás se van, fijando así tanto en el papel como en el espacio su estado de transgénero socialmente reconocido y personalmente asumido.

Se mezclan varios géneros a la moda y sus personajes arquetípicos gracias a los cuales logra convertir en un proceso de carnavalización literaria y humana un relato picaresco en relación de méritos, una mujer en hombre, lo prohibido

54. Marrero-Fente (2006: 73-74).

55. Díez Borque (1979: 80).

56. Puede haber unas grietas como en algunas de las novelas cortas de Lope en Las novelas a Marcia Leonarda.

57. Es decir que, aunque haya tenido relaciones sexuales con mujeres, prueba su virginidad según los códigos legales patriarcales que no reconocen como zonas erógenas los genitales femeninos y consideran solamente la relación sexual hombre/mujer (penetración) como probante (la virginidad supone ausencia de penetración). Astuta e irónicamente, sabe valerse del sistema patriarcal y de sus fallas para hacer resaltar su "pureza».

58. Planté (2003: 135).

59. Viennot (2003: 153).

60. Rutter-Jensen (2007: 89) y Areta Marigó (1999: 252) destacaron también el rechazo violento al trato de «señora" y de lo femenino con el uso muy irrespetuoso de la palabra "putas». 
en algo reconocido, premiado y admirado para respaldar su vida extra-ordinaria y convertirse en verdadero héroe-heroína popular: pícaro, monja, conquistador, viajero, doncella guerrera, etc. Más que un personaje ambiguo, andrógino o hermafrodita es un personaje protéico, transgénero ${ }^{61}$ (que viaja tanto por los diferentes géneros literarios que tejen la historia como por los géneros masculino y femenino) el que asume el protagonismo de este relato transgenérico.

\section{Enmascarar desenmascarando: un relato espectacular}

Según Dominique Maingueneau, el posicionamiento por género («positionnement par genre», 1993: 71-74) permite explicar la relación entre lo que dice un texto y lo que hace en su enunciación, es decir que la manera como una obra se apodera de uno o varios géneros tiene y crea sentido. La Historia de la Monja Alférez se vale de varios géneros literarios consagrados para transformar un caso socialmente singular y transgresivo en un personaje literario proteico pero convencional y para subvertir la división genérica literaria, que suele corresponder a la segmentación genérica entre lo masculino y lo femenino. ${ }^{62}$ La operación narrativa ejecuta una transformación de la heterodoxia en ortodoxia, la literatura es el respaldo para la anormalidad o el proceso alquímico de transformación del plomo en oro.

Los papeles literarios que desempeña el protagonista pueden entenderse como una metáfora de los roles de géneros que son el rol de hombre y el de mujer que desempeńó en su vida, sugiriendo entonces que son máscaras, que forman parte de una vasta representación social. La habilidad del/la narrador(a) radica en mostrarse al principio como un travestí muy a su pesar, por necesidad (cuando el lector puede suponer que fue por gusto al leer sus aventuras posteriores). Es así como quiere que lo veamos: quiere que creamos que se parece a un hombre siendo mujer. Su estrategia es jugar con las apariencias, confundir la máscara con la cara y mezclar realidad y ficción para borrar las fronteras.

La dimensión teatral del relato y del personaje se puede observar en la anécdota siguiente:

Estábame un día de fiesta en la comedia en mi asiento que había tomado, y sin más atención, un fulano Reyes vino y me puso otro tan delante y tan arrimado que me impedía la vista. Pedíle que lo apartase un poco, respondióme desabridamente, y yo a él, y díjome que me fuese de allí que me cortaría la cara. Yo me hallé sin armas,

61. Prefiero optar por el término "transgénero" a pesar de lo que dice Rutter-Jensen a propósito de su preferencia por «transexual» porque «transgénero» abarca también la dimensión genérica literaria que constituye uno de los procesos de su operación narrativa de «transformación».

62. Por ejemplo no se conoce ningún caso de relaciones de servicios y méritos escritas por una mujer para defender sus propias acciones. Las mujeres que escribieron algunas eran viudas que pedían dinero por los méritos de sus esposos difuntos. 
más que una daga, salíme de allá con sentimiento. Entendido por unos amigos, me siguieron y sosegaron. (103)

El episodio de la comedia a la que Erauso asiste en la ciudad peruana costeña de Zaña es muy famoso. Vengativo, el protagonista Alonso Díaz Ramírez de Guzmán espera al lunes siguiente para dar un escarmiento al presumido Reyes. Después de verlo pasar por la calle, cierra la tienda de la que está encargado por su amo Juan de Urquiza, recoge cuchillo — «hícele amolar y picar el filo, como sierra» (103) — y espada — «que fue la primera que ceñí»—y sale a retar a Reyes:

—iAh, señor Reyes!—. Volvió él y dijo: —¿Qué quiere?-. Dije yo: —Ésta es la cara que se corta-,y dile con el cuchillo un refilón de que le dieron diez puntos. Él acudió con las manos a su herida; su amigo sacó la espada y vínose a mí, y yo a él con la mía. Tirámonos los dos, y yo le entré una punta por el lado izquierdo, que lo pasó y cayó. Yo al punto me entré en la iglesia que estaba allí. (103)

La evocación del mundo teatral, de la comedia a la que asiste funciona como un espejo: no habla de la obra que se representa sino del acontecimiento que ocurre entre los espectadores y que es una escena característica de una obra de teatro con el tema del honor ultrajado y la posterior venganza. La afrenta y la amenaza de cortarle la cara tienen un eco especial: es como teatro fuera (y no dentro) del teatro, una manera de sugerir que el teatro rebasa los límites del escenario. Desaparecen las fronteras entre realidad y ficción, el espectáculo teatral penetra lo que se considera el mundo real en el relato y enfoca la atención del lector en las "caras» heridas, cortadas. La réplica de Erauso-Díaz Ramírez de Guzmán («Ésta es la cara que se corta») es digna de una comedia y hasta de un título llamativo.

La reacción del protagonista se explica de dos maneras: primero la amenaza de cortarle la cara podría entenderse como el riesgo de destruir su máscara; luego las armas escogidas anuncian una pelea violenta, sangrienta, gracias a la que reivindica su fuerza masculina (física y simbólicamente) y su condición de espadachín temible. Es a partir de esta escena cuando se van a suceder a lo largo de la obra una larga serie de escenas, situaciones teatrales como si Erauso nunca saliera del corral de comedia en el que entró. El desenlace es a su vez característico de una comedia de capa y espada ${ }^{63}$ en que el enredo se complica con un lío amoroso. En efecto, después del ardid de la inmunidad eclesiástica —al que recurre muy frecuentementeJuan de Urquiza acude a Zaña para salvar a su protegido y le propone la solución del matrimonio con dońa Beatriz de Cárdenas, tía de la esposa de Reyes. Nuestro protagonista no se caracteriza por su ingenuidad y extrae deducciones acertadas:

Es de saber que esta dońa Beatriz de Cárdenas era dama de mi amo, y él miraba a tenernos seguros, a mí para servicio y a ella para gusto. Y parece que eso tratado entre

63. Arellano (1996: 38). 
los dos lo acordaron, porque después que fui a la iglesia restituido, salía de noche, iba a lacasa de aquella señora, y ella me acariciaba mucho, y con son de temor de la justicia me pedía que no volviese a la iglesia de noche, y me quedase allá; y una noche me encerró y se declaró en que a pesar del diancho había de dormir con ella, y me apretó en esto tanto que hube de alargar la mano y salirme. (104)

El triángulo amoroso sugerido por el amo, de índole picaresca, es imposible porque Erauso tiene que seguir disimulando su sexo femenino, como sabe muy bien el lector.

Con estos episodios se afianza la ironía dramática del relato. El desfase entre lo que ignoran los personajes diegéticos y lo que sabe el lector crea una tensión narrativa. La prueba del reconocimiento constituye el riesgo mayor de su vida. La experimenta desde muy joven cuando acaba de huir del convento y es paje en la casa de Juan de Idiáquez en Valladolid, secretario del rey y gran amigo del padre de Catalina de Erauso. Su padre, en busca de la hija prófuga, llega a la casa de Idiáquez y mientras otro paje va a buscar al secretario, se queda en la sala con su progenitor — «sin hablarnos palabra ni él conocerme» (96). Luego decide irse y después de varias aventuras por los caminos del norte de España, regresa a San Sebastián a poner a prueba su nueva apariencia: «allí me estuve sin ser de nadie conocido, bien vestido y galán. Y un día oí misa en mi convento, la cual oyó también mi madre, y vide que me miraba y no me conoció» (97). Enfrentarse a sus padres y a sus paisanos es el último examen que aprueba para salir definitivamente a vivir su nueva vida en el Nuevo Mundo. Tampoco su hermano reconoce a su «hermanita Catalina la monja» (112) en Chile. El desdoblamiento del narrador es evidente en este fragmento ya que a través del discurso indirecto de su hermano, se refiere a Catalina con la tercera persona, como si se tratara de otra persona.

Rutter-Jensen subraya que «la exitosa transición de Erauso a hombre depende principalmente de la representación de la masculinidad, no de una asociación natural, de nacimiento, entre hombre y masculinidad» (90); es decir, que a lo largo de la narración, se desarrolla un verdadero one-man show que pone en evidencia lo que se quiere mostrar. Cabe observar que su grado militar es el de alférez: es el portaestandarte del ejército así como de sus méritos varoniles. Pendenciero, violento, seductor, agresivo, aficionado al juego, es el arquetipo del militar español conquistador (conquistar tierras significa penetrarlas) y el/la narrador(a) hace de lo que presentó primero como una máscara la verdadera identidad del protagonista.

Según Maravall, en el Barroco la realidad es otra ilusión porque se percibe con los sentidos que suelen engañar a los hombres: no se sabe cuándo «en ese juego de imágenes se pasa de lo representado a lo real» (1975: 402), de ahí que «el tópico del mundo como teatro, del hombre como actor, de la vida como comedia [...] se renuev[e] profundamente en los escritores barrocos» (1975: 403). Las múltiples confusiones entre realidad y ficción y entre los géneros/sexos obliga al lector a adaptar constantemente su enfoque. Este juego de perspectivas se asemeja 
a una anamorfosis literaria ${ }^{64}$ en la que un personaje proteico (el mito de Proteo es otro de los grandes mitos que reaparecen en el Barroco) juega constantemente a ser y a no ser. Este relato dramatizado de su vida espectacular, "the theatre of self-representation", muestra que "gender is nothing more than disguise and performance» ${ }^{65}$ Cambia sus identidades e invierte los papeles a su antojo, cuando quiere ser hombre o cuando necesita ser mujer. No deja de jugar con los otros personajes - material y metafóricamente- y con el lector. La omnipresencia de su afición a los juegos de naipes no es sino una metáfora de su afición al juego, al engaño. El trans-vestismo es constitutivo del texto y del personaje que asume diferentes roles en una (auto-)representación que oscila entre teatro y carnaval, de ahí la gran dificultad de los lectores para decidirse en cuanto a su identidad. En efecto, para Bajtín, la diferencia entre carnaval y teatro es que en el primer caso se vive la representación carnavalesca, la ilusión es la realidad, mientras que en el segundo se pone a distancia la representación, lo que permite protegerse al mostrar que ser un hombre es una ilusión y que se tiene conciencia de ella. Las transiciones sutilmente conducidas entre estas dos modalidades de representación vivida y a distancia ritman la narración y culminan en la anagnórisis final.

Irónicamente, el momento que debería ser el clímax del triunfo de la verdad resulta ser el engaño magistral de la estrategia narrativa del relato. A lo largo de sus aventuras, Erauso no ha dejado de portarse mal, cuando no de modo anticlerical. Muchos comentaron este episodio clave pero pocos recalcaron la parquedad $^{66}$ con la que Erauso relata su vida al obispo de Guamanga:

—Señor, todo esto que he referido a V.S. ilustrísima no es así; la verdad es ésta: que soy mujer, que nací en tal parte, hija de fulano y sutana; que me entraron de tal edad en tal convento, con fulana mi tía; que allí me crié; que tomé el hábito; que tuve noviciado; que estando para profesar, por tal ocasión me salí: que me fui a tal parte, me desnudé, me vestí, me corté el cabello; partí allá y acullá; me embarqué, aporté, trajiné, maté, herí, maleé; correteé, hasta venir a parar en lo presente, y a los pies de su señoría ilustrísima. (160)

Además de los talentos narrativos que cautivaron al obispo por varias horas, de la reducción de su vida a una serie de acciones que callan o disimulan el

64. José Antonio Maravall la define de la siguiente manera: «por un juego de deformaciones, de distorsiones practicadas sobre el objeto, se pretende conseguir que a primera vista éste desaparezca o, mejor dicho, se aproxime en su apariencia o se asemeje a cosa muy distinta, para restablecerse en la forma sensible de su propia realidad, ante el ojo del espectador, cuando éste lo contempla desde un determinado punto de vista. Son juegos de perspectiva que siempre se usaron, pero que en el Renacimiento, al juntarse un mayor saber geométrico con una intensa curiosidad por los efectos mágicos, empezaron a difundirse, para hacerse muy frecuentes en el Barroco, siendo un ejercicio de virtuosismo en la ciencia geométrica de la perspectiva, muy gustado en el xviI.» (Maravall, 1975: 446-447)

65. Pancrazio (2001: 464).

66. Pancrazio (2001: 471). 
cambio de género, se puede notar que recurre a la confesión bajo la mirada de un confesor benevolente, prueba de sinceridad, pero con un tono muy ligero y coloquial. La imprecisión ("tal», "fulano y sutana», «fulana»), la brevedad con la que se relata el momento de la revelación contrastan con la duración del suceso en la historia y evidencian un desajuste sospechoso. Asimila situaciones de valoración moral muy diferente: insiste en la vestimenta para evocar su ingreso en la orden religiosa (gracias a la expresión consagrada «tomé el hábito») y su ingreso en el mundo masculino («me vestí»). Unas páginas después, cuando cuenta su ingreso en el convento de las clarisas de Guamanga, utiliza otra vez la misma expresión pero con un giro pasivo ("púsome el hábito»). Para Erauso ser monja - o mujer en su caso - es una máscara que le salva la vida (un one-woman show esta vez), aunque tenga que encerrarse de nuevo, lo que rehúye visceralmente. ${ }^{67}$ Una vez en Lima, después de ofrecerle la posibilidad de escoger el convento donde quedarse (escoge el de San Bernardo), su único objetivo es salir cuanto antes del encierro explicando que nunca había profesado (lo que calló seguramente antes cuando refirió su vida al obispo): «allí me estuve cabales dos años y cinco meses, hasta que volvió de España razón bastante de cómo no era yo ni había sido monja profesa; con lo cual se me prometió salir del convento» (164). De paso por Bogotá, cuando el obispo santafereño la invita a quedarse en otro convento, invoca el mismo motivo: «Yo le dije que no tenía yo orden ni religión, y que trataba de volverme a mi patria, donde haría lo que pareciese más conveniente para mi salvación» (165).

Erauso mantiene con la iglesia una relación puramente interesada. Lo demuestra varias veces, especialmente en un famoso episodio reescrito más tarde por Ricardo Palma. ${ }^{68}$ En La Paz, después de matar a un criado por una nimiedad, está encarcelado. Condenado a muerte, lo confiesan y escucha misa en la cárcel cuando, siguiendo los consejos de su confesor franciscano, después de la comunión escupe la hostia «en la palma de la mano derecha» clamando "iglesia me llamo, iglesia me llamo» y se arma un escándalo (144-145). Todos lo tratan de «hereje», el obispo llega y todos los representantes del clero lo conducen en una procesión hasta la iglesia para purificar la hostia en el sagrario. Erauso está donde quería y ya no va a salir del recinto sagrado durante un mes antes de huir con la ayuda de amigos. Por otra parte, la revelación de su verdadera identidad ocurre en Guamanga, en el capítulo xx, después de haber matado a una enésima víctima y de resistir a los alguaciles contestándoles en una última bravuconada, cuando le pidieron su nombre, que era "el diablo» (159).

A la luz de estos elementos, un lector atento puede adivinar la superchería latente y auténtica: la confesión —el estilo coloquial adoptado delata su artifi-

67. Confiesa que no le gusta quedarse demasiado tiempo en el mismo lugar (cap. I): «pasado ese tiempo, sin más causa que mi gusto, dejé aquella comodidad» (97).

68. Véase la tradición «iA Iglesia me llamo!» (tercera serie de las Tradiciones peruanas, 1875). 
cialidad - es su salvación más material que espiritual, como lo deja suponer la respuesta ambigua que le dirige al obispo de Bogotá. Asimismo la revelación de su identidad de mujer es en realidad el disimulo de su identidad de hombre, el género que escoge más por gusto que por necesidad.

La habilidad del relato radica en una inversión espectacularmente irónica que hace parecer mentira lo que es verdad (ser —o querer ser- hombre) y verdad lo que es mentira (ser mujer y monja, una identidad que quiso ocultar). Se puede establecer una relación con los resortes de las comedias a partir de la dramatización de un conflicto aparente (muy común en la comedia) entre voluntad propia y deber, entre libertad y orden. La anagnórisis final sería el punto de inflexión del restablecimiento del orden (una sociedad con dos géneros en la que es mujer aunque disfrazada de hombre). Pero no hay que fiarse de las apariencias: al final no regresa a la norma social del matrimonio (es demasiado vieja) o del encierro (no es monja profesa). No se trata de un círculo, aunque a primera vista lo parece. Se trata de una espiral ascendente porque esta vez logra huir del convento con los honores y la seguridad que le aseguran su edad, su castidad y sobre todo su fama.

Ahora bien, su astucia narrativa no lo explica todo: el reconocimiento inmediato que logra en América y a su regreso de América no fue el resultado de los efectos de la Historia de la Monja Alférez porque no la había escrito — que fuera Erauso u otro el autor - sino de otros factores muy importantes que el texto aborda también.

\section{El paso por América: movilidad por el espacio del self-made man}

En sintonía con su época, la Historia de la Monja Alférez sabe sacar provecho de los éxitos de su tiempo. Maravall recuerda que al hombre barroco le fascina lo nuevo: «Lo extraño, lo extraordinario, lo que se sale de lo normal, son manifestaciones de la novedad» (1975: 455). El escenario americano es el espacio perfecto para que se opere el cambio genérico de Erauso pero sobre todo para que pueda vivir la vida aventurera que le gusta. El Nuevo Mundo es el continente de lo fantástico, de lo no fijado (es un mundo en expansión donde segundones o hidalgos pobres pueden medrar y realizar el sueño americano), de lo ex-céntrico (el famoso lema "acatan pero no cumplen» caracterizó el comportamiento de muchos chapetones o gachupines, españoles de América y criollos, ayudados por la lejanía). Es el mundo de lo posible o de lo imposible, según la perspectiva que se adopte: América es el espacio del desplazamiento de la norma, de la construcción de sí mismo por sus acciones, sus servicios y sus méritos según la terminología de la época. Entonces, además de ser el continente donde se puede cambiar de estatuto o de posición, ¿por qué no sería también el espacio que permita cambiar de género (en la medida en que el género se entiende como otro rol social que se atribuye — injustamente - al nacer), requisito absoluto para poder vivir sin trabas, como un hombre? 
El recorrido de Erauso narrado en 26 capítulos, ${ }^{69}$ que corresponden cada uno a una etapa o escala en algún sitio de la Península o del virreinato del Perú, es también una forma de aprendizaje. Literariamente, son varios modelos de personajes viajeros (doncella guerrera andante, pícaro, conquistador) los que sustentan el viaje y más precisamente el viaje a los márgenes. Narrativamente, es la huida necesaria del convento (aunque sea voluntaria). Genéricamente, son diferentes tipos de relatos de la movilidad — geográfica y/o social— (relación de méritos y servicios, relato picaresco) los géneros que se explotan en esta dimensión itinerante del relato. ${ }^{70}$

América es un espacio en expansión perpetua: una vez conocidas todas las tierras continentales, los españoles prosiguen las exploraciones en los mares, hacia el sur y el oeste, hacia el Mar del Sur, es decir el Pacífico. Los centros se desplazan y los márgenes se extienden. En este contexto, la movilidad es la manera fundamental de dominar el territorio. El personaje protagonista de la Historia de la Monja Alférez se inscribe en esta cinética y se caracteriza por su dinamismo, tanto en sus desplazamientos como en las etapas que hace.

Si se realiza la tipología de sus acciones, se pueden destacar cinco modalidades: el viaje (por mar o tierra), la etapa-servicio (sirve a varios amos y vive más o menos tranquilamente hasta que le ocurra algo - mata a varios hombres- y que tenga que huir - la del convento encaja en este tipo de etapas), la etapamilitar (expediciones o guerras contra los indígenas, como en Chile, que lo llevan a los márgenes del imperio), la etapa-amorío (propuestas de matrimonio o galanteo que provocan su huida) y por fin la etapa-reconocimiento (se presenta a los grandes que la reciben o se la reconoce por la calle).

La repartición de los tipos de etapas corresponde también a la progresión del relato y de la intriga. La etapa-servicio y la etapa-militar son dos modalidades que aparecen sobre todo en los primeros capítulos, en los que domina el relato picaresco y el relato militar, cuando sirve a varios amos y cuando procura ganar honores, es decir en una fase juvenil de relativa autonomía y de construcción de su identidad masculina social (de mercader pasa a ser soldado). La etapa-amorío se multiplica en los primeros capítulos y repite siempre el mismo esquema: seduce a mujeres y cuando la situación se pone complicada (competición con otro hombre, en este caso su propio hermano, como en el capítulo VI, o peligro de ser reconocida si acepta el matrimonio como en Tucumán — pero sí acepta un anticipo de la dote). Luego este tipo de etapa

69. En su edición, Rima de Vallbona reunió los últimos seis capítulos en uno solo (el capítulo xx) que presenta la unidad temática del reconocimiento.

70. Otros tipos de relatos de viaje como el relato de peregrinación pueden intervenir en la obra: durante el paso de los Andes después de su huida del fuerte militar, el Alférez Díaz Ramírez de Guzmán experimenta el miedo frente a lo macabro - otro tema barroco que remite a la vanidad - cuando divisa a lo lejos a dos siluetas que son en realidad dos hombres que «estaban muertos, helados, las bocas abiertas como riendo" (121). 
evoluciona y se vuelve más compleja: empieza a proteger a mujeres en apuros como en el capítulo X cuando ayuda a doña Catarina de Chaves hasta la cárcel donde sufre tortura; en el capítulo XIII vuelve a proteger a una mujer adúltera, dońa María Dávalos, huye con ella y logra llevarla a un convento adonde, según lo que confiesa, visita «muchas veces a [su] monja» (141).

Erauso recorre una gran parte del virreinato del Perú, desde Cartagena de Indias hasta Concepción, pasando los Andes hasta Tucumán, regresando a Potosí, moviéndose principalmente entre las provincias de Chile, la Plata, el Alto Perú y el mismo Perú. Todos los capítulos, con excepción de uno o dos, empiezan sistemáticamente con la llegada a un sitio y se terminan con la salida a otro, sin objetivo o meta determinados, excepto en los últimos en los que se determinan rumbos precisos, una vez «recobrada» lo que la sociedad de aquel entonces considera su identidad original oficial.

El suceso de la revelación de su identidad es un verdadero punto de inflexión en el relato que provoca una inversión inesperada: de hombre pasa otra vez a ser mujer, troca el anonimato por la celebridad, los pecados en virtudes $y$, de nuevo, la vida andariega por el convento. Según la propia narradora, en la conclusión de otro episodio (capítulo X, cuando se borra su condena después del «caso Catarina de Chaves»), «estos milagros suelen acontecer en estos conflictos, y más en Indias, gracias a la bella industria» (131). «La maravilla de las Indias fue edificada sobre una inmensa estrategia seductora» señala Gema Areta Marigó (1999: 246). América aparece como la Tierra de promisión o de atracción para todos aquellos que no encuentran su sitio, un sitio fijo, en otras sociedades.

Por lo tanto, el protagonista cambia también de tipo de espacios: de los márgenes pasa a los centros. Emprende lo que llamaríamos hoy en día una verdadera gira mundial. Sus próximas etapas son las grandes ciudades del mundo occidental: primero conoce al virrey en Lima, don Francisco de Borja, Príncipe de Esquilache, se va a Santafé de Bogotá y luego a Cartagena de Indias, el gran puerto de donde sale a España (capítulos XXI y XXII). Llegada a España, pasa por Sevilla, por Madrid, donde se presenta al rey para entregarle su relación de méritos y servicios y pedirle una renta, lo que acepta el soberano (como en la comedia, cuando el rey interviene al final para restablecer o establecer el orden). Lo vuelve a ver en Barcelona después de sufrir el ataque de unos bandoleros que le robaron cuanto tenía. El rey parece conocer su fama de espadachín al contestarle: «¿Pues cómo os dejasteis vos robar?» (171). Llega por fin a Italia y acude a Roma a conocer al papa Urbano VIII que después de escuchar el relato de sus aventuras le otorga un favor excepcional: «me concedió licencia para proseguir mi vida en hábito de hombre» (173).

El viaje por América legitima el cambio y su peculiar dimensión heroica, legendaria; parece otorgarle el salvoconducto que lo/la lleva a las más altas autoridades patriarcales de la época. Los hombres que regresan de América (los indianos son siempre hombres en la literatura) suelen regresar a Europa con un nuevo 
estatus o expedientes que deberían garantizarles un cambio de estatus. ${ }^{71}$ Son self-made men, una expresión del hombre barroco definido por Maravall: «No se le considera como un factum, sino como un proceso: un fieri, un proceso" (1975: 345), en un mundo donde reina «en primer plano la idea de movimiento [...] como principio fundamental del mundo y de los hombres: la nociones de cambio, mudanza, variedad, o de caducidad, restauración, transformación [...] son derivaciones de aquél» (1975: 356-357). Pasar el Atlántico es como pasar el Leteo, el río infernal del olvido que permite regresar al mundo de los vivos para encarnarse en otro cuerpo y adoptar su destino. En el desplazamiento a y por América, la identidad se va a enriquecer al entrar en contacto con nuevos grupos, con nuevos mundos: la identidad se elabora a la vez por los actos, es decir de manera absoluta (sus propias acciones), y por los encuentros con otros, o sea de manera relativa (se pulen nuevas facetas que permiten enriquecer y afinar la identidad del viajero con otras perspectivas).

A lo largo del recorrido americano, Erauso, Díaz Ramírez de Guzmán, la Monja Alférez, hombre o mujer, quienquiera que sea, se enfrenta a otros grupos sociales, culturales, religiosos que le permiten acrisolar su identidad, desviando la atención de los lectores o de las autoridades hacia otros rasgos aún más importantes que el género en aquel entonces: su identidad cultural, religiosa, estamental y familiar. Belén Castro Morales los interpreta como «episodios» que redimen sus crímenes (236-237). Pienso que más que pruebas de buena conducta, los presenta el relato como rasgos fundamentales y fijos de su identidad que compensan su confusión genérica. ${ }^{72}$

La confrontación con otros pueblos, grupos nacionales o religiosos se exacerba en el contexto americano. En América, lo que se consideraría como banal en España (ser español, católico, hidalgo, etc.) se vuelve mucho más cotizado y raro. Además de desviarse, la mirada del lector se deforma: en la lucha contra los araucanos rebeldes (cap. VI), contra los indios de los "Chuncos» — seguramente los chunchos- (cap. IX) o cuando solamente se topa con mulatos o mestizos ${ }^{73}$ (cap. VII), Erauso se presenta como un conquistador superior, valiente y despiadado con los enemigos de la corona, católico y peninsular. El patriotismo de Erauso se consolida también en Italia cuando un italiano le dice que todos

71. No olvidemos que, según Laqueur, el cambio de estatus hubiera podido lógicamente abarcar un cambio de género ya que querer ser hombre era considerado como un ascenso en la escala genérica y, por ende, social.

72. Entran en conflicto dos concepciones de la identidad, una esencialista y otra como performance, precisamente porque hubiera resultado muy difícil, cuando no imposible, sostener en la temprana modernidad una identidad puramente evolutiva. Intento comprender aquí la complejidad de la problemática identitaria que presenta el relato sin imponer un marco teórico demasiado rígido. 73. Después del paso de los Andes, una mujer recoge al alférez debilitado y concibe planes: «Era bien acomodada, y tenía muy muchas bestias y ganados; y como parece que aportan por allí pocos Españoles, parece que me apeteció para una hija.» (122). 
los españoles son una «merda» (172): lo reta y lo mata. Reafirma su orgullo patriótico cuando un cardenal le dice que su único defecto es ser español: «A mí me parece, señor, debajo de la corrección de vuestra señoría ilustrísima, que no tengo otra cosa buena» (174). El efecto americano deformante opera también en el capítulo Xvir con la lucha épica contra los corsarios holandeses luteranos: después de relatar la batalla naval, cuenta cómo fue capturado por los holandeses que le «hicieron mal tratamiento con burlas y desprecios» (148) y cómo lo soltaron en Paita después de veintiséis días de cautiverio. La defensa nacional, militar y espiritual del imperio español se hace con las armas en las manos, misión digna de un hidalgo como Antonio de Erauso.

Ahora, en una dimensión más individual, se afirman también dos rasgos identitarios muy fuertes e importantes para Erauso: su origen vasco y el lugar ocupado en la hermandad de una familia noble. Su relación con los vascos en la Península y en América es evidente: sus amos se llaman Juan de Urquiza, Juan de Idiáquez, sirve al capitán Eguiño, tío suyo durante la travesía, etc., sus amigos son todos vascos (entre ellos su hermano Miguel de Erauso). Cuando está en apuros, muchos compatriotas suyos le dan consejos «en vascuence» $(107,116)$, dos «Vizcaínos» (152) salen a ayudarlo durante su legendario duelo contra el nuevo Cid en el capítulo XviII. Se alude también en el capítulo VIII a la «guerra entre vicuñas y vascongados» que tuvo lugar en Potosí a principios de los años 1620 para el control de las minas de plata. Se evoca el alzamiento de Alonso Ibánez, capitán de los vicuñas (el resto de los peninsulares y los criollos) y el compromiso de Erauso en el bando de los vascos. Los estrechos vínculos que lo unen con sus compatriotas vascos le permiten reafirmar su pertenencia a un pueblo particularmente favorecido por la corona. ${ }^{74}$

Por fin, se puede mencionar las relaciones con su familia: en el relato aparecen sus padres pero también un tío suyo y varios hermanos. Entre los últimos el más famoso es Miguel de Erauso, capitán que participa en las guerras de Chile y a quien mata trágicamente en un duelo por culpa de la oscuridad. Borrachero Mendíbil nota además que durante el tornaviaje navega con dos hermanos suyos para los cuales obtiene favores del general de la armada, don Fadrique de Toledo: «el asesinato de Miguel se presenta como la realización de una fantasía: la eliminación de una figura que ocupa el lugar de preeminencia social y familiar que Erauso desea para sí». ${ }^{75}$ Considerado ahora como el primogénito, actúa como tal con sus hermanos menores. Esta posición en la hermandad está reconocida en el testamento de su madre en el que figura bajo el nombre de Antonio de Erauso, ${ }^{76}$ el nombre que Catalina escoge llevar después de su reconocimiento. Este nuevo

74. Vaca de Osma (2001).

75. Borrachero Mendíbil (2006: 492).

76. Adrienne L. Martín (1994: 36) precisa que en el testamento del padre (más temprano), aparece con su identidad femenina, Catalina de Erauso. 
posicionamiento en la familia es el más envidiable: de hija segundona pasa a ser hijo primogénito con todos los favores que incumben a tal hidalgo.

Estos encuentros, confrontaciones, oposiciones, constituyen marcadores fundamentales de su identidad, de la identidad que busca delinear el relato. La estructura narrativa del relato de viaje, a veces desunido o muy abrupto por las múltiples etapas y las consiguientes aventuras, sirve un doble propósito: mostrar el recorrido vital, un auténtico y muy concreto curriculum vitae, y poner en perspectiva la identidad que se fragua y que afirma el/la narrador(a)-protagonista. El viaje a América permite relativizar ciertas cosas y reforzar otras gracias al lente deformante que se aplica a los diferentes aspectos que constituyen su identidad in fieri. Su identidad se completa, se enriquece y no podemos olvidar estos aspectos más tradicionales aun cuando el problema de género parece ser el mayor problema de su definición o, por lo menos, el que más se resalta por motivos seguramente sensacionalistas. Este último no borra los demás, sobre todo en aquella época en que son sumamente importantes. Es más, sin las otras facetas de su identidad, no se hubiera podido desarrollar tanto las intrigas debidas a la confusión genérica.

Los actos y los vínculos sociales ${ }^{77}$ son los fundamentos de la construcción errante de su identidad según las expectativas del lector de principios del siglo XVII. En un nivel geográfico pero también simbólico, su trayectoria desde un espacio marginal hasta un espacio central se aclara gracias a sus actos y méritos codificados por un discurso patriarcal (masculino, imperial) y deformados por el filtro americano. La adecuación entre su identidad y los valores de este sistema, a pesar de todos los crímenes cometidos, le aseguran la posibilidad de metamorfosis en Ifis, por lo menos a nivel social (quedando problemática la transformación física). Sin embargo, los elementos que acabo de analizar, las estrategias tanto material como simbólicamente elaboradas en la Historia de la Monja Alférez, no bastan aún para explicar el reconocimiento total y unánime que logra por parte de todos los grandes del mundo occidental, lo que no deja de sorprendernos y disimula seguramente otros recursos, más invisibles y crípticos que voy a tratar de exponer.

\section{Una vasta campańa de (auto-)promoción: reconocimiento y posteridad}

La Historia de la Monja Alférez se inserta en una operación de comunicación de gran amplitud: además de la legitimación de las aventuras gracias a la encarnación de personajes y tipos literarios que tranquilizan proponiendo modelos conocidos y de la validación del género merced al replanteamiento de su identidad en un contexto americano, se organiza una campaña promocional visual (con el encargo de retratos), política (conoce a las máximas autoridades) y sociocultural (difusión de

77. John Jeffries Martin (2004: 19), en su ensayo Myth of Renaissance individualism, explica que «for many, one's identity was largely prescribed by the larger social groups (family' guild' community) to which one belonged». 
obras, de relaciones que cuentan la vida o episodios de la vida de la Monja Alférez). Se puede muy lógicamente preguntar cómo, con qué recursos este personaje, por más extraordinario que fuera, logró difundir su leyenda para alcanzar la fama que le garantizaba también el reconocimiento de las autoridades.

Para contestar bien a esta pregunta, sería necesario realizar investigaciones históricas que aclaren la red clientelar de los allegados de Erauso y su influencia. Por falta de tiempo no he podido buscar estas informaciones pero quiero proponer pistas de reflexión que puedan aportar algunos indicios. La cantidad de crímenes que confiesa el/la narrador(a) a lo largo del relato pueden ser muy graves: asesinatos y engańos (justificados desde un punto de vista literario como crímenes de honor - comedia-, desde un punto de vista épico-histórico como parte de la "guerra justa» y desde un punto identitario como una necesidad de travestirse) que podían llevar a la horca o a la cárcel (tenemos muchos ejemplos de ello en el relato pero nunca se materializa la condena porque siempre ocurre un acontecimiento inesperado que salva a Erauso). Adrienne L. Martín recuerda también que «el travestismo fue prohibido tanto por la ley canónica como por la civil». ${ }^{78}$ Los cargos se multiplicaron y, a los ojos de la ley de aquella época, hubiera podido ser además una mujer que transgredía la norma indumentaria de la época.

El relato evoca la ayuda constante de sus paisanos vascos y de la Iglesia. Acaso se pueda formular la hipótesis según la cual su reconocimiento oficial — muy sorprendente si consideramos sus pecados y crímenes - pudiera ser obra de un lobby más extenso y disimulado, que supiera orquestar hábil y magistralmente su campańa de promoción o autopromoción. El perdón, la protección y la admiración unánimes otorgados por las más altas autoridades patriarcales de la época (virreyes, privados, rey, obispos, arzobispos, papa) así como los medios convocados para difundir su leyenda (fueran orales, visuales o literarios - comedias, relaciones, etc.) fueron extraordinarios y no dejan de despertar la duda en cuanto a las verdaderas razones de su reconocimiento y de su fama. Los vascos tenían un poder comercial (remito al episodio histórico de las guerras entre vicuńas y vascongados para el control de las minas de plata), disponían de privilegios particulares como lo recuerda el/la narrador(a) en el capítulo X: ${ }^{79}$ cuando está en apuros o en una situación peligrosa, los vascos interceden y negocian con las autoridades. En el caso de la guerra entre los vicuñas y los vascos, el relato presenta a estos últimos como a los defensores del orden imperial ya que salen gritando «Viva el rey» (125) a prender a los demás españoles presentados como

78. Martín (1994: 38). Explica también (1994: 37) que el lesbianismo no existía como base de acusación (no perdían su virginidad según los códigos patriarcales). Solo se encontraba el cargo de «sodomita» que aseguró a las mujeres más protección a no ser que usaran un instrumento fálico. 79. Encarcelado y acusado de varios crímenes, se nos relata el episodio como sigue: «Yo negué totalmente saber del caso; luego pasó a me mandar desnudar y poner en el potro. Entró un procurador alegando ser yo vizcaíno, y no haber lugar por tanto a darme tormento por razón de privilegio» (131). La cursiva es mía. 
insurrectos peligrosos que defienden «La libertad» (125). Se subraya la importancia de la red vasca, su poder, su solidaridad así como su riqueza y su lealtad al rey. Hay que contar con ellos, representan una casta poderosa a la que se puede difícilmente negar privilegios (recuérdese la tradición de los fueros vascos respetados por los Reyes católicos), ${ }^{80}$ sobre todo en los siglos XVI y XVII, cuando los gobernantes castellanos quieren integrar las provincias vascas en el espacio comercial castellano para contrarrestar el contrabando. ${ }^{81} \mathrm{~A}$ través de Erauso, ${ }^{82}$ verdadero héroe, es toda una casta de hidalgos vascos que reivindica un reconocimiento más amplio y que reafirma su influencia. No hay que olvidar que uno de los grandes amigos de su padre fue Juan de Idiáquez, secretario de los reyes Felipe II y Felipe III. Erauso se codeó con obispos, arzobispos (de Lima), el virrey don Francisco de Borja, Príncipe de Esquilache. A su regreso, en Madrid, lo/la prenden y es el conde de Olivares quien ordena su liberación. Sin olvidar al rey con el que habla y bromea en Barcelona. En Francia conoce al conde de Gramont, ${ }^{83}$ "conde de Agramonte» (169), el hijo de la famosa «belle Corisande», favorita de Enrique IV, y poderoso señor del suroeste. En Italia coincide con el marqués de Santa Cruz en Génova (173) y frecuenta a cardenales antes de que lo/la reciba el papa Urbano VIII. ${ }^{84}$ Erauso obtiene la autorización de llevar ropa de hombre como otro privilegio. La red vasca pudo ayudar en y fuera de la Península a Erauso (hasta financiar su campańa promocional de miles dei vasca) como lo hizo después de que se escapó del convento y en América cuando estaba en apuros. Uno de los elementos que pueden confirmar esta hipótesis es la difusión de sus aventuras y la construcción de su leyenda gracias al teatro.

En el siglo XVII aparece, además de las relaciones ya citadas, una comedia de Juan Pérez de Montalbán, ${ }^{85}$ La Monja Alférez (probablemente de 1625 también). Es para el personaje una manera de regresar a su cuna dramática. Jules Whicker

80. Vallbona (1992: 172) explica lo siguiente: «uno de los privilegios que por ley tienen los hidalgos de sangre particularmente los de Guipúzcoa, es que no pierdan su hidalguía y nobleza por usar oficios viles y necesarios, aunque hayan caído en suma pobreza».

81. Esteban (2011: 78).

82. A la objeción que se puede hacer acerca de la identidad de Erauso, conviene recalcar lo que observa Vallbona (1992: 2): «Por un lado, los vascos se han distinguido por su individualismo, espíritu de aventura, bizarría y autoconciencia de su fuerza como grupo étnico. La historia del descubrimiento, conquista y colonización de América no quedaría completa si no se incluyera su valiosa y efectiva participación a lo largo de los siglos hasta el presente, como marineros, conquistadores, misioneros, mineros, pastores, mercaderes y colonizadores. Por el otro, el papel prestigioso que desempeña la mujer en la cultura vasca es digno de ser considerado, ya que recientes estudios han hecho evidente el carácter matriarcal de dicha sociedad.» La cursiva es mía.

83. Familia noble de origen navarro y asentada en el suroeste de Francia. Fueron, entre otro, capitanes y gobernadores de Bayona.

84. Educado por los jesuitas (pero no jesuita), Urbano VIII pudo apreciar el primer nombre escogido por Erauso, Francisco Loyola.

85. La comedia está publicada en la edición de Ferrer (169-311). A continuación, cito por esta edición. 
mostró que las certificaciones - que escribieron Francisco Pérez de Navarrete, Luis de Céspedes Xeria, Juan Cortés de Monroy y Juan Recio de León para dar fe de los acontecimientos referidos en la petición redactada por Erauso- alimentaron buena parte de la intriga y fueron también citadas y puestas en escena en la obra. ${ }^{86}$ En la tercera jornada por ejemplo, se menciona varias veces a los amigos que apoyaron la petición. Se delinea una red de amistades y más allá una red clientelar en la que el dramaturgo parece inscribirse, al reproducir parte de los documentos oficiales que le fueron facilitados inmediatamente, dada la fecha de composición. Evoca al amigo vasco que lo/la hospeda en Madrid («Díceme que está el Alférez / en la corte ya, y que posa / en casa de un noble hidalgo, / su amigo, y compatriota, / cuyo nombre es Sebastián de Illumbe», 274). Se reproduce en prosa y literalmente buena parte de la certificación de don Luis de Céspedes Xeria y se inscribe la fecha exacta: «En Madrid a 2 de febrero de 1625» (296) ${ }^{87}$ Sebastián de Illumbe o Ilumbe, como aparece en los archivos, es también un personaje histórico y amigo de Erauso. ${ }^{88}$ Además no se deja de alabar el valor y la nobleza del personaje.

Los críticos subrayaron la discrepancia entre el enredo de la comedia y el relato de la Historia de la Monja Alférez. Creo que se puede matizar este juicio. Es evidente que se ańadieron episodios y elementos para responder a las exigencias teatrales, especialmente el enredo amoroso. No estoy de acuerdo con Ángel Esteban cuando, para explicar las diferencias, comenta que «en la comedia Catalina se niega a reconocer que es mujer» (42). En la Historia tampoco busca este reconocimiento y se confiesa únicamente para salvarse y muy a regañadientes. Asimismo el estudioso dice que "hay un rechazo general a la feminidad que no existe en los manuscritos» (42), lo que desmiente el desenlace del relato con los insultos proferidos hacia las damiselas que la ofenden al llamarla «señora». La comedia, igual que la Historia, se acaba con la confesión de su condición femenina, cuando ya no tiene otra opción para salvar el honor de su querida dońa Ana, sacrificando su orgullo.

Lo interesante de la comedia es que da cuerpo a la teatralización del personaje: Esteban escribe que Erauso aparece como el «estereotipo del galán fanfarrón» (42); es la hipérbole de este tipo de personaje teatral, a propósito. La Monja Alférez, llamada Guzmán en la comedia, no deja de rechazar su condición femenina y reta a quienes se atreven a recordárselo. En la tercera escena de la tercera jornada, sale con su amigo y consejero Sebastián de Illumbe (284) que le insta a vestirse de mujer y a aparecer públicamente como una mujer para conocer a los funcionarios del rey. Guzmán resiste con vehemencia antes de ceder

86. Whicker (2004: 1852).

87. El cotejo con el documento oficial guardado en el Archivo General de Indias y reproducido en Vallbona (1992: 134) no deja ninguna duda al respecto.

88. Vallbona (1992: 1133). 
y vestirse "de lo que aborrezco tanto» (283). Se revela de cierta manera la estrategia de Erauso y de su red de amistad que entendieron perfectamente la importancia de reconocer la identidad femenina - de forma muy teatral, mediante el tópico de la mujer disfrazada de hombre—, según los códigos de la época. A pesar de que Guzmán se perciba como hombre («Estoy tan acostumbrado.../ Acostumbrada...» le corrigen, 287), tiene que ser mujer a los ojos de la sociedad: es precisamente el sentido de la confesión final (se restablece el orden) y lo muestra el teatro a un público amplio. Es solamente a esta condición que se le permite vestirse de hombre, porque el travestismo es el menor de los males que no cuestiona - y hasta reafirma - la existencia de dos géneros. ${ }^{89} \mathrm{La}$ comedia se puede leer como una puesta en escena del guión de mayor amplitud elaborado por Erauso y sus allegados y forma parte, muy probablemente, de la campańa promocional ingeniada. Unas investigaciones históricas más serias permitirían seguramente indagar este aspecto y confirmar o invalidar esta idea.

Muy lógicamente, un personaje tan teatral y tan polifacético conocerá posteriormente un gran éxito en las artes escénicas o visuales (teatro, cine) y en la literatura de forma más general. María Asunción Gómez ${ }^{90}$ y Sherry Velasco han in-

89. La voluntad de ser leído/a como una mujer disfrazada de hombre, como un travestí, es el corazón de esta estrategia. Pero no se trata más que de un travestismo travestido porque la Monja Alférez no se concibe como tal: «una ilusión hecha real es el más eficaz testimonio del carácter ilusorio de la realidad" (Maravall 1975: 406). La tercera parte de la relación publicada en México en 1653, después de su muerte (ya que nos la cuenta este relato) destapa una parte del enigma: cuando ya vive en Nueva Espańa y se desempeña desde hace varios ańos como arriero, conocido como mujer pero bajo el nombre de Antonio de Erauso, se enamora perdidamente de una joven hasta retar en duelo al marido porque éste le prohíbe visitar a su esposa. El marido rechaza el duelo porque le dice que no pelea contra una mujer, lo que saca literalmente de quicio a Antonio que empieza a atacar por las calles a cuántos hombres pasan. Si Catalina/Antonio vive plenamente su masculinidad, la sociedad, aunque parece aceptarlo, le niega el acceso al matrimonio y por lo tanto a la sexualidad. Al final, Erauso no consigue el reconocimiento como transexual (no puede cambiar de sexo) sino como transgénero: se le concede la posibilidad de vivir como un hombre, siendo mujer, pero no la posibilidad de ser un hombre, según la concepción tradicional de la identidad en la sociedad moderna. A pesar de la benevolencia de las autoridades, la sociedad se encarga de hacerle pagar lo que el saber y la tecnología médicos le prohibían. Es como si al fin y al cabo las autoridades benevolentes supieran que los límites científicos o prácticos tendrían la última palabra y que la trampa de la estrategia de presentarse como un travestí lo/la encerraría en este traje convencional. Erauso retoma entonces el camino con su recua, es decir una vida andante que es el único modo de vida que le permite vivir su identidad trashumante y morir en una última etapa americana, en una parte indeterminada (jotra!) entre México y Veracruz.

90. Gómez (2009). De Las aventuras del Bachiller Trapaza (1637) de Castillo Solórzano, donde se introduce al legendario personaje de la Monja Alférez como un engaño, una farsa que funciona muy bien y que permite hacerse rico, pasando por varias novelas románticas (la famosa The Spanish Military Nun, 1847, de Thomas de Quincey), novelas y obras dramáticas finiseculares que oscilan, de forma nada sorprendente, entre la figura de mujer santa, víctima y la mujer diabólica, cruel, sin plantearse cuestiones de género - es claramente una mujer virtuosa disfrazada de hombre-, hasta la recuperación del personaje en el siglo Xx que tiene un éxito particular en el cine con la película mexicana La Monja Alférez (1944), dirigida por Emilio Gómez Muriel, con 
ventariado todas las obras en la que la Monja Alférez tiene el papel principal o un papel secundario y explicado cómo se realizó su apropiación por distintos medias en distintas épocas. ${ }^{91}$ Esta última muestra muy bien cómo la recepción de la obra empezó con una indeterminación en cuanto al género (ambigüedad no zanjada en cuanto a su homosexualidad) en el siglo xvII para seguir con una neutralización de esta faceta en el siglo xIx (y hasta la primera mitad del siglo $\mathrm{xx}$ ) y terminar con un nuevo cuestionamiento de la homosexualidad y más allá del género. Añade que la recuperación del personaje en España fue también motivado por consideraciones ideológicas —el director de la película de 1986 es vasco y participa en la construcción de un personaje heroico vasco muy popular en la actualidad en esta región: «The hybrid nature of the Lieutenant Nun allowed both the liberal Republicans as well as the opposing fascist Francoists to evoke Erauso as a symbol of their political ideology. For the first group, the Lieutenant Nun represented a challenge to repressive patriachal control while the latter saw Erauso as a symbol of conservative nationalistic and religious ideals. After Franco's death, the Basque government was also motivated to reappropriate Erauso's story as an example of the regional pride that was suppressed under the dictatorship." ${ }^{92}$

La operación narrativa y de comunicación fue - y sigue siendo- - un éxito total: «Lo que la ortodoxia normativa rechaza, lo admite la estética de la desmesura» (Castro Morales, 2000: 239). Cuanto más increíble resulta algo, más posible parece porque la gente piensa que no se puede inventar tantas aventuras. La deformación hiperbólica que sufren tanto la historia como el personaje se construye sin embargo dentro del marco de la tradición y de lo canónico, adoptando varios roles. El personaje casi nace de la literatura, viene respaldado por lo anormal o lo marginal normalizado por y dentro de la literatura. Además, nos dice indirecta e irónicamente, desde el corazón del sistema patriarcal que ninguna de las identidades que lo/la definen es sexual: «La figura de Erauso refuerza la división binaria entre femenino y masculino, al tiempo que representa la elasticidad de dichas categorías» (Rutter-Jensen, 2007: 94). Su identidad elástica se construye a partir de los roles literarios (dramáticos, caballerescos, picarescos, épicos, etc.), sociales (culturales, religiosos, militares, comerciales, sexuales, etc.) que desempeña, potenciados por los diferentes gé-

un guión adaptado por Max Aub y Eduardo Ugarte y protagonizada por María Félix (enfoque tradicional de una película de capa y espada), con la del director español Javier Aguirre, La Monja Alférez (1986), con Esperanza Roy, mucho más matizada con la evocación del lesbianismo o de la identidad masculina de Erauso) o en el teatro con La Monja Alférez (1986) de Domingo Miras que no logra evitar el maniqueísmo genérico y hasta contradice el feminismo esgrimido en algunas escenas. Gómez subraya no obstante el que esta última obra dramática muestre la importancia de la literatura como medio de legitimación: «tanto en su condición de espectáculo teatral como en su condición de espectáculo travestido, queda clara la conexión con la creación literaria y su función en la construcción de identidades para el consumo del público».

91. El trabajo valioso de Sherry Velasco (2001) es imprescindible.

92. Velasco (2001: 169) 
neros literarios convocados más o menos puntualmente a lo largo del relato y por el viaje a y por América.

Transgenéricos, relato y personaje obligan al lector a no pensar según una lógica genérica o a repensar el funcionamiento por géneros y su arbitrariedad. A partir de la constante "paradoja de subversión y reafirmación simultáneas de los discursos ortodoxos» (Rutter-Jensen, 2007: 89), desafían a los lectores y a los investigadores a proponer una lectura definitiva y unívoca. La anamorfosis es enigmática y la metamorfosis es constante, inestable, lo que impide clasificar la obra (¿relación de méritos?, ¿novela picaresca?, ¿autobiografía o biografía?, etc.), determinar quién es el autor, quién es el narrador, quién es el personaje (la identidad polifacética que se lee de diferentes maneras según los lentes que se ponen). La recepción caleidoscópica, «impresionista impregnada por la subjetividad y las expectativas ideológicas de sus críticos» (Castro Morales, 2000: 229) es también la víctima de la manipulación y la confusión hábilmente elaborada para borrar toda respuesta definitiva (que sea judicial, social, política, cultural o interpretativa). El mecanismo de protección, el escudo hermenéutico siguen funcionando y llevan también a otro tipo de reconocimiento: la integración de la obra en el canon literario hispánico e hispanoamericano.

Es indudable que la recepción artística y crítica ha sido tan polifacética como el relato y el personaje. La Monja Alférez se desencarna cada vez más para volver a reencarnarse en uno de los diferentes aspectos de su identidad huidiza (mujer disfrazada de hombre, aventurero, pícaro, etc.). ${ }^{93}$ Como una cáscara vacía, reducida a un disfraz — una consecuencia de la estrategia inicial— se vuelve un personaje-transferencia en el que se proyectan las fantasías o las ideologías de una época dada. Las arenas movedizas de un relato autobiográfico inicial misterioso, probablemente transformado, manipulado, no permiten fijar a este personaje marginal que, al fin y al cabo, revela muchas más cosas de nosotros (críticos, artistas, lectores) y de nuestras lecturas e interpretaciones que del enigma de la Monja Alférez.

93. Velasco (2001: 169). 


\section{Bibliografía}

Fuentes primarias

Erauso, Catalina de, Historia de la Monja Alférez, doña Catalina de Erauso, escrita por ella misma, Joaquín María de Ferrer (ed.), París, Imprenta de Julio Didot, 1829.

—, Vida i sucesos de la Monja Alférez. Autobiografía atribuida a Doña Catalina de Erauso, Rima de Vallbona (ed.), Arizona, Arizona State University, 1992.

-, Historia de la Monja Alférez, doña Catalina de Erauso, escrita por ella misma, Ángel Esteban (ed.), Madrid, Cátedra, 2011, 197.

Fuentes secundarias

BLAsco, Eduardo, Del claustro al campamento o la Monja Alférez: novela historica, Barcelona, Antonio Virgili, 2 vols, 1892.

Castillo Lara, Lucas G., La asombrosa historia de doña Catalina de Erauso, la Monja Alférez, y sus prodigiosas aventuras en Indias (1602-1624), Caracas, Planeta Andina, 1992.

Castillo Solónzano, Alonso de, Las aventuras del bachiller Trapaza, Madrid, Castilla, 1949.

De Quincey, Thomas, La Monja Alférez, Barcelona, Barral Ediciones, 1972.

IвÁŃEz, Ricard, La Monja Alférez. La juventud travestida de Catalina de Erauso, Barcelona, Devir Contenidos, 2004.

Keller, Carlos, Las memorias de la Monja Alférez, Santiago de Chile, J. de Vivar, 1972.

Mateos, Juan Antonio, La Monja Alférez. Drama en tres actos y en verso, México, J.M. Sandoval, 1877.

Miras, Domingo, La Monja Alférez, Murcia, Universidad, 1992.

Morales Álvarez, Raúl, La Monja Alférez (crónica de una vida que tuvo perfil de romance), Santiago de Chile, Excelsior, 1938.

Ochoa, María del Carmen, La Monja Alférez, Madrid, G. del Toro, 1970.

Palma, Ricardo, Tradiciones peruanas completas, Madrid, Aguilar, 1957.

Pérez de Montálban, Juan, La Monja Alférez, en Catalina de Erauso, Historia de la Monja Alférez, doña Catalina de Erauso, escrita por ella misma, José María de Ferrer (ed.), París, Imprenta de Julio Didot, 1829.

Rodríguez, Armonía, De monja a militar, Barcelona, La Gaya Ciencia, 1975, 124.

Obras teóricas y críticas

Amelang, James S., «La autobiografía moderna entre la historia y la literatura», Chronica Nova 32 (2006), pp. 143-157.

Arellano, Ignacio, «El modelo temprano de la comedia urbana de Lope de Vega", Lope de Vega: comedia urbana y comedia palatina, Felipe B. Pedraza Ji- 
ménez, Rafael González Cañal (coord.), Almagro, Universidad de CastillaLa Mancha, Festival de Almagro, 1996, pp. 37-59.

Areta Marigó, Gema, «El barroco y sus máscaras: Vida y sucesos de la Monja Alférez», Anuario de estudios americanos, 56-1 (1999), pp. 241-252.

Armas Wilson, Diana de, “A imitación de las amazonas': mujeres aguerridas en La Araucana", Mujer y cultura en la Colonia hispanoamericana, Mabel Moraña (ed.), Pittsburgh, Instituto internacional de literatura iberoamericana, 1996, pp. 23-34.

AugÉ, Marc, Non-lieux. Introduction à une anthropologie de la surmodernité, París, Seuil, 1992.

Bakhtine, Mikhaill, La poétique de Dostö̈evski, París, Seuil, 1970.

Behbahani, Soraya (dir.), Ce genre qui dérange, París, Téraèdre, 2009.

Corbin, Alain, Courtine, Jean-Jacques, Vigarello, Georges (dir.), Histoire de la virilité, París, Seuil, 2011.

Beling de Benassy, Marie-Cécile, «A manera de apéndice: Sor Juana y el problema del derecho de las mujeres a la enseñanza», La mujer en el teatro y la novela del siglo XVII, Toulouse, France-Ibérie recherche, Université de Toulouse-le Mirail, 1979, pp. 89-93.

Borrachero Mendíbil, Aránzazu, "Catalina de Erauso ante el patriarcado colonial: estudio de Vida $i$ sucesos de la Monja Alférez», Bulletin of Hispanic Studies, 83-6 (2006), pp. 485-497.

Bravo-Villasante, Carmen, La mujer vestida de hombre en el teatro español (siglos XVI-XVII), Madrid, Sociedad General Española de Librería, 1976.

Castro Morales, Belén, "Catalina de Erauso, la monja amazona", Revista de critica literaria latinoamericana, 52 (2000), pp. 227-242.

Delpech, François, «La leyenda de la Serrana de la Vera: las adaptaciones teatrales», La mujer en el teatro y la novela del siglo XVII, Toulouse, France-Ibérie recherche, Université de Toulouse-le Mirail, 1979, pp. 23-38.

Díez Borque, José María, «El feminismo de Doña María de Zayas», La mujer en el teatro y la novela del siglo XVII, Toulouse, France-Ibérie recherche, Université de Toulouse-le Mirail, 1979, pp. 61-88.

Fougeyrollas-Schwebel, Dominique, Planté, Christine, Riot-Sarcey, Michèle, Zaidman, Claude (dir.), Le genre comme catégorie d'analyse. Sociologie, histoire, littérature, París, L'Harmattan, 2003.

Gómez, María Asunción, «El problemático 'feminismo' de La Monja Alférez de Domingo Miras», Espéculo. Revista de estudios literario 41 (2009), 01/11/13 $<$ http://www.ucm.es/info/especulo/numero $41 /$ monjalfe.html

La mujer en el teatro y la novela del siglo XVII, Toulouse, France-Ibérie recherche, Université de Toulouse-le Mirail, 1979.

Herpoel, Sonja, “Un mar de misterios': la religiosa española ante la escritura», Breve historia feminista de la literatura española (en lengua castellana). IV. La literatura escrita por mujer (De la Edad Media al s. XVIII), Puerto RicoBarcelona, Universidad de Puerto Rico, 1997, pp. 205-223. 
Jefrries Martin, John, Myth of Renaissance individualism, New York, Palgrave Macmillan, 2004.

Laqueur, Thomas, La fabrique du sexe. Essai sur le corps et le genre en Occident, París, Gallimard, 1992.

Lejeune, Philippe, Le pacte autobiographique, París, Seuil, 1975.

Luna, Lola, "Dos escritoras para la historia: Valentina Pinelo y Ana Caro", Breve historia feminista de la literatura española (en lengua castellana). IV. La literatura escrita por mujer (De la Edad Media al s. XVIII), Puerto Rico-Barcelona, Universidad de Puerto Rico, 1997, pp. 243-279.

Maingueneau, Dominique, Le contexte de l'ouvre littéraire: énonciation, écrivain, société, París, Bordas, 1993.

Maravall, José Antonio, La cultura del Barroco, Barcelona, Ariel, 1975.

Marín Pina, María Carmen, "Aproximación al tema de la virgo bellatrix en los libros de caballerías españoles», Criticón, 45 (1989), pp. 81-94.

Marrero-Fente, Raúl, "Género, retórica y derecho en la autobiografía de la monja alférez», La ansiedad autorial. Formación de la autoría femenina en América latina: los textos autobiográficos, Márgara Russotto (dir.), Caracas, Universidad Simón Bolívar, Equinoccio, 2006, pp. 59-74.

Martín, Adrienne L., "Desnudo de una travestí o la 'autobiografía de Catalina de Erauso'", La mujer y su representación en las literaturas hispánicas, Juan Villegas (coord.), Irvine, University of California, 1994, vol. 2, pp. 34-41.

Mataix Azuar, Remedios, "Androcentrismo, eurocentrismo, retórica colonial: Amazonas en América», América sin Nombre 15 (diciembre de 2010), pp. $118-136$

Merrim, Stephanie, "Catalina de Erauso y Sor Juana Inés de la Cruz», $Y$ diversa de mi misma entre vuestras plumas ando. Homenaje internacional a Sor Juana Inés de la Cruz, Sara Poot Herrera (ed.), México, Colegio de México, 1993, pp. 355-365.

Moraña, Mabel (ed.), Mujer y cultura en la Colonia hispanoamericana, Pittsburgh, Instituto internacional de literatura iberoamericana, 1996.

PAncrazio, James J., «Transvested Autobiography: Apocrypha and the Monja Alférez», Bulletin of Hispanic Studies, 78-4 (2001), pp. 455-473.

Pérez Villanueva, Sonia, «Historia de la Monja Alférez: ¿escrita por ella misma?», Memoria de la palabra: Actas del VI Congreso de la Asociación Internacional Siglo de Oro, Burgos-La Rioja 15-19 de julio 2002, Francisco Domínguez Matito, María Luisa Lobato López (coord.), Frankfurt am Main, Iberoamericana Vervuert, 2004, pp. 1442-1452.

PlantÉ, Christine, "Genre, un concept intraduisible?», Le genre comme catégorie d'analyse. Sociologie, histoire, littérature, Dominique Fougeyrollas-Schwebel, Christine Planté, Michèle Riot-Sarcey, Claude Zaidman (dir.), París, L'Harmattan, 2003, pp. 127-136.

Poot Herrera, Sara (ed.), $Y$ diversa de mi misma entre vuestras plumas ando. Homenaje internacional a Sor Juana Inés de la Cruz, México, Colegio de México, 1997. 
Rutter-Jensen, Chloe, «La transformación transatlántica de la monja alférez», Revista de Estudios Sociales, 28 (2007), pp. 86-95.

SEgAs, Lise, Le cycle des pirates dans la poésie épique hispano-américaine (15851815), Bordeaux, tesis inédita, 2011.

VACA De Osma, José Antonio, Los vascos en la historia de España, Madrid, Rialp, 2001, 290.

Vega Carpio, Félix Lope de, Arte nuevo de hacer comedias, Enrique García Santo-Tomás (ed.), Madrid, Cátedra, 2006.

Velasco, Sherry, The Lieutenant Nun: Transgenderism, Lesbian Desire and Catalina de Erauso, Austin, University of Texas Press, 2001.

Vienot, Éliane, "Le genre, cet inconnu. Le mot et la chose dans l'étude de l'Ancien Régime», Le genre comme catégorie d'analyse. Sociologie, histoire, littérature, Dominique Fougeyrollas-Schwebel, Christine Planté, Michèle Riot-Sarcey, Claude Zaidman (dir.), París, L'Harmattan, 2003, pp. 153166.

Whicker, Jules, «La virtud militar y el diseño moral de La Monja Alférez de Pérez de Montalbán", Memoria de la palabra: Actas del VI Congreso de la Asociación Internacional Siglo de Oro, Burgos-La Rioja 15-19 de julio 2002, Francisco Domínguez Matito, María Luisa Lobato López (coord.), Frankfurt am Main, Iberoamericana Vervuert, 2004, pp. 1851-1860.

Zavala, Iris M., Breve historia feminista de la literatura española (en lengua casteIlana). IV. La literatura escrita por mujer (De la Edad Media al s. XVIII), 1997, Puerto Rico-Barcelona, Universidad de Puerto Rico.

Filmografía

Gómez Aguirre, Javier, La Monja Alférez, Madrid, Goya films, 1986.

Muriel, Emilio, La Monja Alférez, México, 1944.

McLaughuin, Sheila, She Must Be Seeing Things, USA, 1987. 
